\title{
Synthesis and herbicidal activity of new substituted 2- and 4-pyrimidinyloxyphenoxypropionate derivatives
}

\author{
Tong-Hui Huang, Hai-Yang Tu,* Zumureti Aibibu, Chang-Jian Hou, and Ai-Dong Zhang* \\ Key Laboratory of Pesticide and Chemical Biology of Ministry of Education, College of \\ Chemistry, Central China Normal University, Wuhan 430079, PR China \\ E-mail: adzhang@mail.ccnu.edu.cn, haiytu@mail.ccnu.edu.cn
}

\begin{abstract}
Aryloxyphenoxypropionates (APPs) are a class of herbicides targeting acetyl-CoA carboxylase (ACCase) in monocot chloroplast. The article presents the rational design and synthesis of a series of APPs with 2- and 4-pyrimidinyloxy moieties. The developed synthetic protocols are versatile and allow convenient functionalization of the phenoxypropionate core with various 2or 4-pyrimidinyl moieties via the oxygen bridge by taking advantage of the reactivity difference between 2-methylsulfonyl and 4-chloro on the pyrimidine ring. Preliminary bioassay shows that most of title compounds have good herbicidal activities against rape and barnyard grass at 100 $\mathrm{mg} / \mathrm{L}$. Several compounds are more potent to inhibit the stalk growth of barnyard grass than the commercial herbicide cyhalofop.
\end{abstract}

Keywords: Aryloxyphenyloxypropionate, 2-methylsulfonylpyrimidine, 4-chloropyrimidine, synthesis, herbicidal activity

\section{Introduction}

Acetyl-CoA carboxylase (ACCase, EC 6.4.1.2) in plants is a key enzyme in de novo fatty acid biosynthesis, catalyzing the carboxylation of acetyl-CoA to malonyl-CoA. ${ }^{1}$ There are two forms of ACCase in most plant families: the heteromeric form in plastids and the homomeric form in cytoplasm, with the exception of the grass family, including wheat and rice, which have the homomeric form in both cytosol and plastids. ${ }^{2}$ The homomeric ACCase in grass plastids is the selective action target of aryloxyphenoxypropionate (APP) herbicides, ${ }^{3}$ which were introduced in the 1980s and have been extensively used worldwide to control a variety of grass weeds. The frequent use of this class of herbicides has resulted in an increasing resistance in many grass weeds. ${ }^{4}$ Developing new herbicides that inhibit both the susceptible and resistant forms of ACCase in grass weeds would have obvious commercial appeal. ${ }^{5}$

Some typical commercial APP herbicides (I: diclofop; II: cyhalofop; III: haloxyfop) are 
shown in Figure 1, which have the same phenoxypropionate portion, but different aryloxyl rings. The structures of the yeast (Saccharomyces cerevisiae) ACCase carboxyl transfer (CT) domain in complexes with diclofop I and haloxyfop III have been solved by x-ray diffraction. The typical binding pattern revealed that the aryloxyl groups were sandwiched between the side chains of two conserved amino acids Tyr-1738 and Phe-1956' in ACCase active site with obvious $\pi-\pi$ interaction force. ${ }^{6}$ For higher plants, Delye and colleagues demonstrated the five residues Ile1781 Trp-2027, Ile-2041, Asp-2078, and Gly-2096 in the active site of ACCase from Alopecurus myosuroides (black-grass) were involved in sensitivity to ACCase inhibitors, as demonstrated through a molecular, biological and biochemical approach combining with the three-dimensional modeling. Zhu and colleagues built the homology models of the ACCase CT domain from the sensitive and resistant foxtails and investigated the molecular mechanism of herbicide resistance and stereochemistry-activity relationships of APPs. ${ }^{7}$ The results indicated that not only the conserved residues for the $\pi-\pi$ stacking but also the hydrogen binding environment were implicated in the binding modes of sensitive and resistant ACCase CT domains.
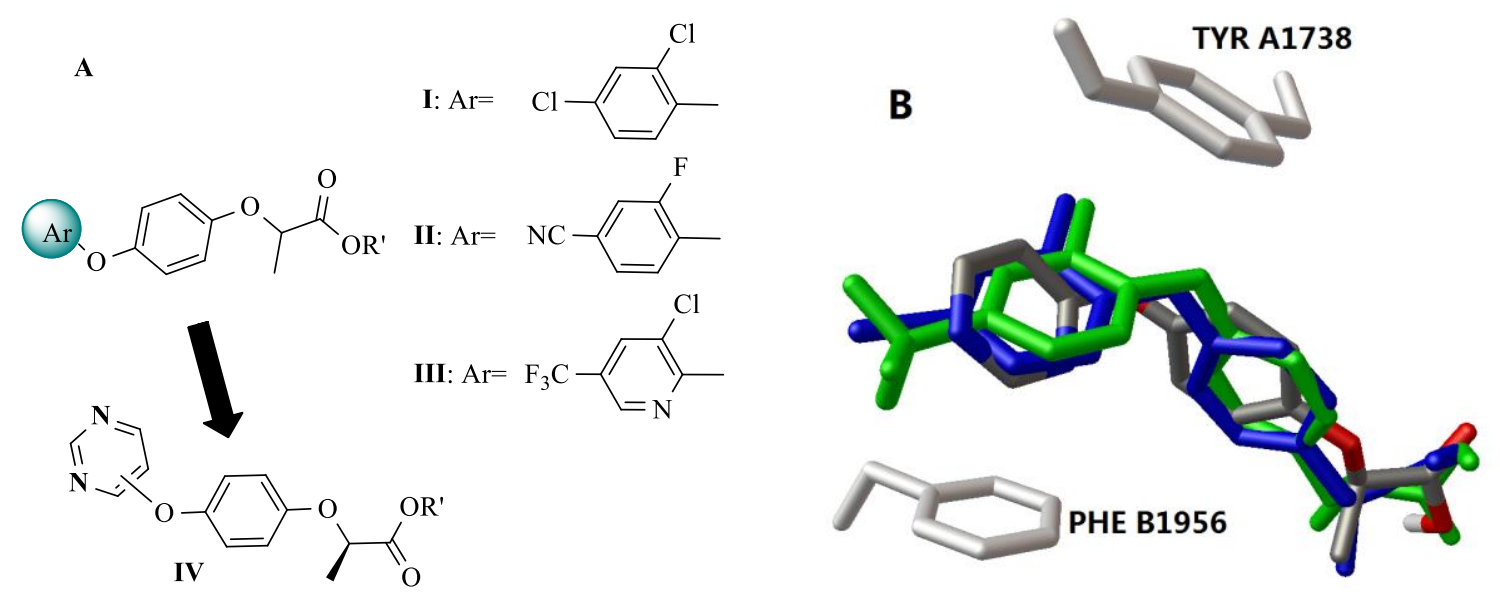

Figure 1. Strategy for the design of pyrimidinyloxyphenoxypropionates. A) Comparison in bioisosterism: I: diclofop; II: cyhalofop; III: haloxyfop; IV: Representative in this work; B Clustering of docked pyrimidinyl-4-oxyphenoxypropionic acid (IV, in atom color) with diclofop (in green) and haloxyfop (in blue) from crystal with the referred residues TYR A1738 and PHE B1956 in ACCase active site.

In our case, we intend to rationally design and synthesise new inhibitors targeting ACCase with the pyrimidinoxyl group as the substituent of aryloxyl portion in conventional APPs. The rational design was firstly considered according to the bioisosterism of pyrimidine ring with benzene and pyridine rings in diclofop I, cyhalofop II, and haloxyfop III, respectively (Figure 1A). ${ }^{8}$ Secondly, the pyrimidine ring is an extremely versatile building block for the manufacture of bioactive compounds such as herbicides, ${ }^{9}$ fungicides ${ }^{10}$ or insecticides ${ }^{11}$ in the agrochemical industry. However, there is limited literature disclosing the potential application of 
pyrimidinyloxyphenoxypropionate compounds as herbicides. ${ }^{12}$ Thirdly, molecular docking of our designed pyrimidinyloxyphenoxypropionic acid (IV) into the active site of ACCase model results in the similar binding pattern as diclofop and haloxyfop in crystal $^{6}$ (figure 1B) with comparable expected bioactivity. Moreover, since a subtle change of substituent on the aryloxyl ring will produce a significant difference on the sensitivity to ACCase, ${ }^{13}$ the attempt to synthesize and identify new compounds that may target ACCase will be valuable for finding a solution against the resistance development in use of the herbicides.

Aimed at the ultimate goal, this work presents the synthesis of pyrimidinyloxyphenoxypropionates and the preliminary bioassay on Brassica napus (rape) and Echinochloa crusgalli (barnyard grass). The developed synthetic protocols are versatile and allow convenient functionalization of the phenoxypropionate core with various 2- or 4pyrimidinyl moieties via the oxygen bridge, by taking advantage of the reactivity difference between 2-methylsulfonyl and 4-chloro moieties on the pyrimidine ring (Scheme 3). Since the enantiomer with $R$ configuration at $\alpha$-position in the propionate portion is more sensitive than its $S$ enatiomer, ${ }^{14}$ L-lactate is used as the chiral pool in synthesis of the desired products with $R$ configuration. Meanwhile, the molecular structure of a representative compound has been characterized with X-ray diffraction.

\section{Results and Discussion}

\section{Docking study}

ACCase is a multidomain enzyme composed of three domains: biotin carboxylase, biotin carboxyl carrier protein, and carboxyltransferase, shorten as BC, BCCP, and CT domains respectively. ${ }^{15}$ The CT domain contains 800 residues and constitutes two subdomains with antisymmetric dimer arrangement, and the active site is located at the interface of the dimer. Two representative herbicides, haloxyfop and diclofop, bind to the active site and the binding mode with yeast ACCase has been resolved by X-ray diffraction. ${ }^{6}$ The main binding pattern is the aryloxy portions of the two inhibitors were sandwiched between the side chains of Tyr-1738 and Phe-1956' with similar orientation and showing $\pi-\pi$ interactions. The amino acid sequences of this domain are highly conserved. For example, there is a sequence identity of $51 \%$ between the CT domains of foxtail and yeast $\mathrm{ACCases}^{7}$ and $55.3 \%$ between that of yeast and black-grass ACCases. ${ }^{3}$ These sequence identities imply the yeast CT domain is sufficient to achieve a satisfactory model. ${ }^{16}$ Therefore, the 3D structure of the yeast CT domain should be applicable to the high plant CT domains for molecular docking.

For the docking of designed pyrimidinyloxyphenoxypropionate, several steps were involved. 1) The model of CT domain was prepared by extracting water molecules and diclofop from the yeast CT complex (PDB code: 1UYT); 2) The active site was chosen as the docking center and the residues Tyr-1738 and Phe-1956' chosen as flexible; 3) Autodock 4.2 program with MGLTools 1.5.2 interface software was used to perform and analyze the docking; 4) The most 
favorable docked conformation was used for visualization and prediction of the binding energy and bioactivity. The clustering of docked pyrimidinyloxyphenoxypropionic acid (IV) with diclofop and haloxyfop in crystal is shown in Figure 1B. The predicted binding energies of most favorable docked conformations were $-6.36,-5.41$ and $-5.19 \mathrm{Kcal} / \mathrm{mol}$, with respect to the three compounds, and all predicted inhibition constants were in the range of millimole. The key feature of pyrimidinyloxyphenoxypropionic acid in docking state is the pyrimidine ring sandwiched between the side chains of Tyr-1738 and Phe-1956', as the binding modes of diclofop and haloxyfop (Figure 1B). When the pyrimidine ring bears substituent(s), stronger binding with larger binding energy can be predicted. Thus the lead hit, pyrimidyloxyphenoxypropionic acid, was chosen for the design and synthesis of series of substituted 2- and 4-pyrimidinyloxyphenoxypropionate derivatives in this paper.

\section{Chemistry}

The design and synthesis of series of substituted 2- and 4-pyrimidinyloxy phenoxypropionate derivatives are outlined in Scheme 1-3. As shown in Scheme 1, hydroquinone was reacted with the chiral pool, methyl $(S)$-2-(tosyloxy)propanoate or ethyl $(S)$-2-(tosyloxy)propanoate, in the presence of sodium hydroxide, and (R)-2-(4-Hydroxy-phenoxy)-propionates 1 were produced.<smiles>CCCCC(C)(C)OC(=O)[C@H](C)OS(=O)(=O)c1ccc(C)cc1</smiles>

Scheme 1. Reagents and conditions: (a) $\mathrm{NaOH}, \mathrm{MeOH}, 40{ }^{\circ} \mathrm{C} ; \mathrm{HCl}$ acid.

The condensation of 1,3-dicarbonyl derivatives $\mathbf{2}$ with thiourea $\mathbf{3}$ followed by the reaction with dimethyl sulfate to afford 2-methylthiopyrimidines 4, which were converted to intermediates 5 by chlorination with $\mathrm{POCl}_{3}$ (Scheme 2).

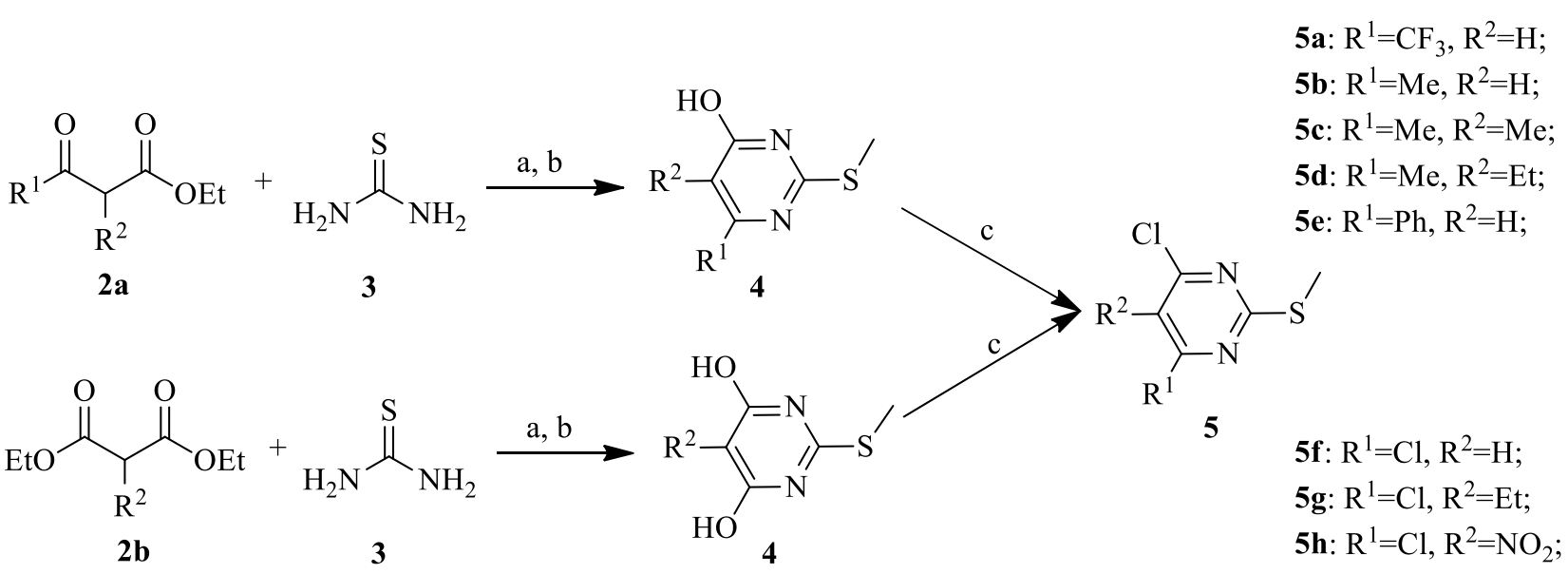

Scheme 2. Reagents and conditions: (a) $\mathrm{NaOMe}, \mathrm{MeOH}$, reflux; (b) $\mathrm{SO}_{2}(\mathrm{OMe})_{2}, \mathrm{NaOH}, \mathrm{H}_{2} \mathrm{O}$, r.t.; $\mathrm{HCl}$ acid; (c) $\mathrm{POCl}_{3}$, DMA, reflux. 
The intermediates 5 could be further derivatized either to the 2-(methylthio)pyrimidines $\mathbf{6}$ by reacting with various alcohols or amines, or to the 4-chloro-2-(methylsulfonyl)pyrimidine derivatives 9 by oxidation with meta-chloroperoxybenzoic acid ( $m$-CPBA) in $\mathrm{CH}_{2} \mathrm{Cl}_{2}$ at room temperature. The 2-methylthiopyrimidines 6 were oxidized to the 2-methylsulfonylpyrimidines 7 with the similar oxidation conditions, whereas the 4-chloro-2-methylsulfonylpyrimidines 9 were converted to 2-alkoxy or 2-alkylamino- 4-chloropyrimidines $\mathbf{1 0}$ by the similar substitution conditions. The intermediates $\mathbf{5 , 7 , 9}$ or $\mathbf{1 0}$ were reacted with the chiral pool $(R)-2-(4-$ hydroxyphenoxy)propanoate 1 in the presence of $\mathrm{K}_{2} \mathrm{CO}_{3}$ in $\mathrm{CH}_{3} \mathrm{CN}$ at refluxing condition to afford the title compounds $\mathbf{8 a}-\mathbf{m}$ and 11a-m (Scheme 3 ).

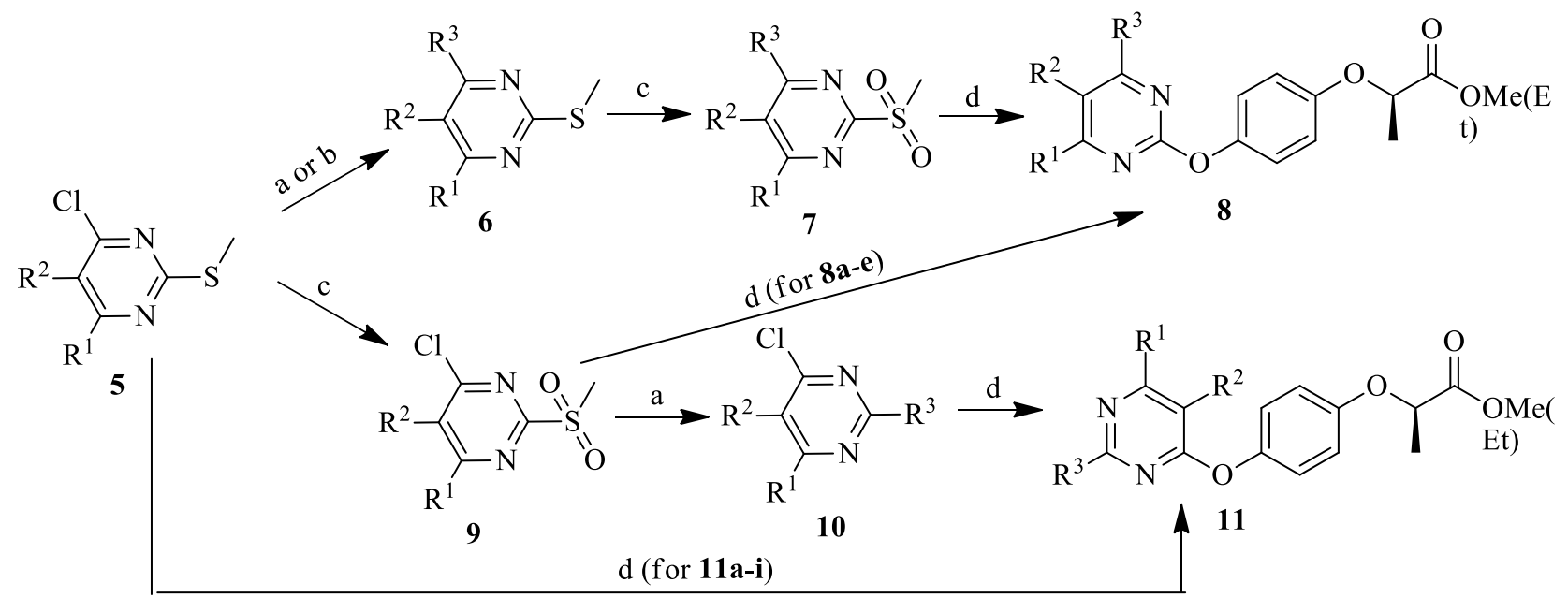
8a: $\mathrm{R}^{1}=\mathrm{CF}_{3}, \mathrm{R}^{2}=\mathrm{H}, \mathrm{R}^{3}=\mathrm{Cl}$;
11a: $\mathrm{R}^{1}=\mathrm{CF}_{3}, \mathrm{R}^{2}=\mathrm{H}, \mathrm{R}^{3}=\mathrm{SMe}$;
8b: $\mathrm{R}^{1}=\mathrm{Me}, \mathrm{R}^{2}=\mathrm{H}, \mathrm{R}^{3}=\mathrm{Cl}$;
11b: $\mathrm{R}^{1}=\mathrm{Me}, \mathrm{R}^{2}=\mathrm{H}, \mathrm{R}^{3}=\mathrm{SMe}$;
8c: $\mathrm{R}^{1}=\mathrm{Cl}, \mathrm{R}^{2}=\mathrm{H}, \mathrm{R}^{3}=\mathrm{Cl}$;
11c: $\mathrm{R}^{1}=\mathrm{Me}, \mathrm{R}^{2}=\mathrm{Me}, \mathrm{R}^{3}=\mathrm{SMe}$;
8d: $\mathrm{R}^{1}=\mathrm{Cl}, \mathrm{R}^{2}=\mathrm{Et}, \mathrm{R}^{3}=\mathrm{Cl}$;
11d: $\mathrm{R}^{1}=\mathrm{Me}, \mathrm{R}^{2}=\mathrm{Et}, \mathrm{R}^{3}=\mathrm{SMe}$;
8e: $\mathrm{R}^{1}=\mathrm{Cl}, \mathrm{R}^{2}=\mathrm{NO}_{2}, \mathrm{R}^{3}=\mathrm{Cl}$;
11e: $\mathrm{R}^{1}=\mathrm{OMe}, \mathrm{R}^{2}=\mathrm{H}, \mathrm{R}^{3}=\mathrm{SMe}$;
8f: $\mathrm{R}^{1}=\mathrm{CF}_{3}, \mathrm{R}^{2}=\mathrm{H}, \mathrm{R}^{3}=\mathrm{OMe}$;
11f: $R^{1}=\mathrm{NHMe}, \mathrm{R}^{2}=\mathrm{H}, \mathrm{R}^{3}=\mathrm{SMe}$;
8g: $R^{1}=\mathrm{CF}_{3}, \mathrm{R}^{2}=\mathrm{H}, \mathrm{R}^{3}=\mathrm{OEt}$;
11g: $\mathrm{R}^{1}=\mathrm{Cl}, \mathrm{R}^{2}=\mathrm{H}, \mathrm{R}^{3}=\mathrm{SMe}$;
8h: $\mathrm{R}^{1}=\mathrm{CF}_{3}, \mathrm{R}^{2}=\mathrm{H}, \mathrm{R}^{3}=\mathrm{NHMe}$;
11h: $\mathrm{R}^{1}=\mathrm{Cl}, \mathrm{R}^{2}=\mathrm{NO}_{2}, \mathrm{R}^{3}=\mathrm{SMe}$;
8i: $R^{1}=\mathrm{CF}_{3}, \mathrm{R}^{2}=\mathrm{H}, \mathrm{R}^{3}=\mathrm{Me}$;
11i: $\mathrm{R}^{1}=\mathrm{Ph}, \mathrm{R}^{2}=\mathrm{H}, \mathrm{R}^{3}=\mathrm{SMe}$;
8j: $R^{1}=\mathrm{Me}, \mathrm{R}^{2}=\mathrm{H}, \mathrm{R}^{3}=\mathrm{OMe}$;
11j: $\mathrm{R}^{1}=\mathrm{Cl}, \mathrm{R}^{2}=\mathrm{H}, \mathrm{R}^{3}=\mathrm{OMe}$;
8k: $\mathrm{R}^{1}=\mathrm{Me}, \mathrm{R}^{2}=\mathrm{H}, \mathrm{R}^{3}=\mathrm{NHMe}$;
11k: $\mathrm{R}^{1}=\mathrm{OMe}, \mathrm{R}^{2}=\mathrm{H}, \mathrm{R}^{3}=\mathrm{OMe}$;
8I: $\mathrm{R}^{1}=\mathrm{Cl}, \mathrm{R}^{2}=\mathrm{NO}_{2}, \mathrm{R}^{3}=\mathrm{OMe}$;
11I: $\mathrm{R}^{1}=\mathrm{OEt}, \mathrm{R}^{2}=\mathrm{H}, \mathrm{R}^{3}=\mathrm{OEt}$;
8m: $\mathrm{R}^{1}=\mathrm{OMe}, \mathrm{R}^{2}=\mathrm{H}, \mathrm{R}^{3}=\mathrm{OMe}$;
11m: $\mathrm{R}^{1}=\mathrm{Cl}, \mathrm{R}^{2}=\mathrm{H}, \mathrm{R}^{3}=\mathrm{NHMe}$;

Scheme 3. The synthetic routes of the title compounds. Reagents and conditions: (a) RONa, $\mathrm{ROH}$, r.t.; (b) $\mathrm{RNH}_{2}, \mathrm{Et}_{3} \mathrm{~N}, \mathrm{BuOH}$, reflux; (c) m-CPBA, $\mathrm{CH}_{2} \mathrm{Cl}_{2}$, r.t.; (d) (R)-methyl or ethyl 2(4-hydroxyphenoxy)propanoate, $\mathrm{K}_{2} \mathrm{CO}_{3}, \mathrm{CH}_{3} \mathrm{CN}$, reflux;

In synthesis of the 4-chloropyrimidines 10, we have tried a direct approach using 2,4dichloropyrimidine or its derivatives as the starting materials, because these compounds are 
commercially available and relatively cheap, and the nucleophilic substitution of chloro group on electron-deficient heterocycles is one of the most common methods to prepare the corresponding alkoxy or aryloxy derivatives. However, this straightforward approach suffered one major drawback: a mixture of 10,12 and 13 were obtained with 13 as the main product at the reactant ratio 1:1 (Scheme 4). This tendency provides a direct evidence that 2-chloro on pyrimidine has a relatively lower reactivity toward nucleophilic substitution than 4-chloro group. This approach cannot offer desired products with positions 2, 5 and 6 substituted while leaving the 4-chloro group intact. To overcome the problem, 2-methylsulfonyl were introduced to the position 2 on pyrimidine ring since it has a strong electron-withdrawing property that facilitates the nucleophilic substitution. ${ }^{17}$ Thus 2-methylsulfonylpyrimidine derivatives were reacted with various sodium alcoholates to afford 2-substituted-4-chloropyrimidine derivatives as shown in Scheme 5. The intermediate $\mathbf{1 0}$ can be readily reacted with $(R)$-2-(4-hydroxyphenoxy)propanoate $\mathbf{1}$ in the presence of $\mathrm{K}_{2} \mathrm{CO}_{3}$ in $\mathrm{CH}_{3} \mathrm{CN}$ at refluxing condition to obtain the title compounds $\mathbf{1 1 g - \mathbf { m }}$ in good yields.<smiles>[R2]c1nc(Cl)nc([R2])c1[R]</smiles>

\section{Scheme 4}<smiles>[R]Oc1nc([R])c([R])c(Cl)n1</smiles>

\section{Scheme 5}

All of the title compounds 8 and 11 were confirmed by ${ }^{1} \mathrm{H}$ NMR, IR, MS and elemental analysis. The structure of one representative compound, Ethyl (R)-2-(4-(4,6dimethoxypyrimidin-2-yloxy)phenoxy)propanoate $\mathbf{8 m}$, was further confirmed by single-crystal $\mathrm{x}$-ray analysis (Figure 2). Complete crystallographic data for the structure of target compound $\mathbf{8 m}$ reported in this paper have been deposited in the Cambridge Crystallographic Data Centre as a CIF file (CCDC 775891). Copies of the data can be obtained free of charge on application to CCDC, 12 Union Road, Cambridge, CB2 1EZ, UK (fax: +44-1223-336-033, e-mail: deposit@ccdc.cam.ac.uk). 


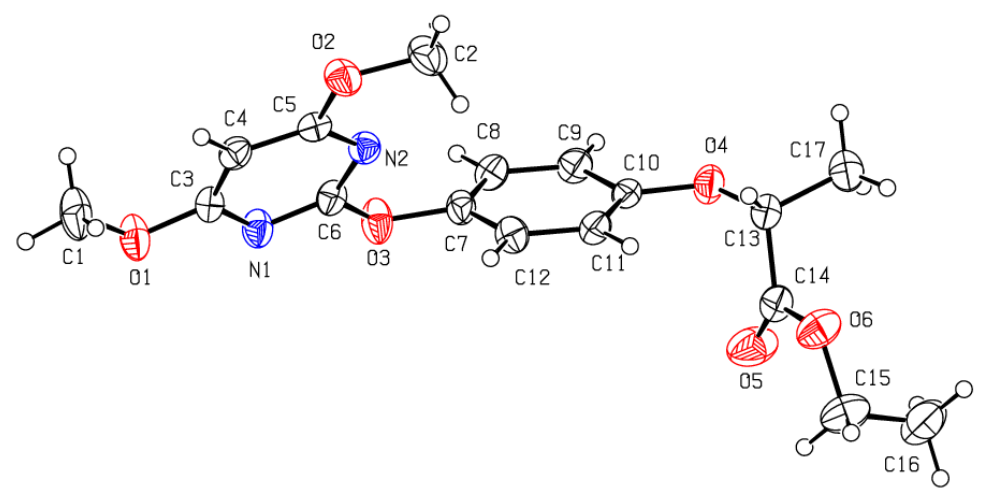

Figure 2. The crystal structure of compound $\mathbf{8 m}$ obtained from single crystal X-ray analysis.

\section{Herbicidal activities}

The herbicidal activities of the synthesized compounds were tested in preliminary assays by using a reported procedure. ${ }^{18}$ As listed in table 1 , most of the compounds showed notable herbicidal activities by inhibiting the root and stalk growth of not only monocotyledonous barnyard grass, but also dicotyledonous rape. For instance, $8 \mathbf{8 f}, \mathbf{8 g}, \mathbf{8 m}, \mathbf{1 1 f}, \mathbf{1 1 h}, \mathbf{1 1 k}$ and $11 \mathrm{~m}$ showed inhibitory rates of $>90 \%$ to the root growth of rape and inhibitory rates of $>80 \%$ to the root growth of barnyard grass at concentration $100 \mathrm{mg} / \mathrm{L}$. It is worth mentioning that most of the compounds were more potent to inhibit the stalk growth of barnyard grass with comparison to the commercial herbicide cyhalofop at concentration $10 \mathrm{mg} / \mathrm{L}$. For example, 8a, 8f, 8h, 11h, 11k, 111 and $11 \mathrm{~m}$ showed inhibitory rates of $>65 \%$ to the stalk growth of barnyard grass at concentration $10 \mathrm{mg} / \mathrm{L}$, whereas the control showed only a low inhibitory capacity to the stalk growth. However, some of these compounds showed low selectivity and with the reduction of concentration to $10 \mathrm{mg} / \mathrm{L}$ these compounds showed low inhibition rates to grass growth with comparison to the commercial herbicide cyhalofop. Meanwhile, of all the tested compounds, $\mathbf{8 h}$, $11 \mathrm{k}, 11 \mathrm{l}$ and $\mathbf{1 1} \mathrm{m}$ to inhibit the growth of barnyard grass and $\mathbf{8 m}$ to inhibit the growth of rape exhibited a relative selectivity in the test weeds at low concentration.

Table 1. The herbicidal activities of title compounds

\begin{tabular}{ccccc}
\hline \multirow{2}{*}{ Compound } & \multicolumn{4}{c}{ Inhibition rate/\% } \\
\cline { 2 - 4 } & \multicolumn{2}{c}{ Rape (root/stalk) } & \multicolumn{2}{c}{ Barnyard grass (root/stalk) } \\
\cline { 2 - 4 } 8a & $100 \mathrm{mg} / \mathrm{L}$ & $10 \mathrm{mg} / \mathrm{L}$ & $100 \mathrm{mg} / \mathrm{L}$ & $10 \mathrm{mg} / \mathrm{L}$ \\
\hline 8b & $91 / 39$ & $47 / 29$ & $79 / 68$ & $62 / 66$ \\
8c & $56 / 58$ & $44 / 36$ & $81 / 74$ & $66 / 59$ \\
8d & $74 / 65$ & $42 / 63$ & $66 / 27$ & $17 / 27$ \\
8e & $69 / 58$ & $51 / 46$ & $71 / 38$ & $43 / 32$ \\
\hline
\end{tabular}


Table 1. Continued

\begin{tabular}{|c|c|c|c|c|}
\hline \multirow{3}{*}{ Compound } & \multicolumn{4}{|c|}{ Inhibition rate $/ \%$} \\
\hline & \multicolumn{2}{|c|}{ Rape (root/stalk) } & \multicolumn{2}{|c|}{ Barnyard grass (root/stalk) } \\
\hline & $100 \mathrm{mg} / \mathrm{L}$ & $10 \mathrm{mg} / \mathrm{L}$ & $100 \mathrm{mg} / \mathrm{L}$ & $10 \mathrm{mg} / \mathrm{L}$ \\
\hline $8 f$ & $93 / 51$ & $42 / 24$ & $89 / 57$ & $64 / 67$ \\
\hline $8 g$ & $96 / 88$ & $69 / 46$ & $90 / 55$ & $64 / 61$ \\
\hline $8 h$ & $56 / 42$ & $32 / 15$ & $82 / 65$ & $70 / 68$ \\
\hline $\mathbf{8 i}$ & $93 / 49$ & $41 / 31$ & $76 / 55$ & $59 / 48$ \\
\hline $8 \mathbf{j}$ & $46 / 43$ & $41 / 35$ & $79 / 72$ & $69 / 64$ \\
\hline $\mathbf{8 k}$ & $76 / 62$ & $71 / 49$ & $80 / 61$ & $60 / 50$ \\
\hline 81 & $89 / 58$ & $69 / 45$ & $77 / 67$ & $70 / 58$ \\
\hline $8 m$ & $98 / 82$ & $96 / 72$ & $87 / 59$ & $48 / 9$ \\
\hline $11 \mathbf{a}$ & $69 / 47$ & $60 / 26$ & $70 / 63$ & $39 / 58$ \\
\hline $11 b$ & $72 / 56$ & $44 / 24$ & $89 / 37$ & $70 / 30$ \\
\hline $11 c$ & $51 / 50$ & $12 / 32$ & $56 / 37$ & $35 / 32$ \\
\hline 11d & $53 / 50$ & $30 / 43$ & $70 / 63$ & $54 / 43$ \\
\hline $11 e$ & $79 / 54$ & $38 / 26$ & $70 / 69$ & $48 / 46$ \\
\hline $11 f$ & $90 / 70$ & $52 / 20$ & $81 / 62$ & $47 / 61$ \\
\hline $11 \mathrm{~g}$ & $62 / 48$ & $55 / 41$ & $71 / 46$ & $60 / 39$ \\
\hline $11 \mathrm{~h}$ & $91 / 57$ & $63 / 44$ & $84 / 70$ & $59 / 65$ \\
\hline $11 \mathrm{i}$ & $81 / 58$ & $70 / 36$ & $88 / 70$ & $72 / 56$ \\
\hline $\mathbf{1 1 j}$ & $76 / 69$ & $58 / 51$ & $70 / 68$ & $62 / 46$ \\
\hline $11 k$ & $98 / 86$ & $47 / 52$ & $91 / 71$ & $78 / 77$ \\
\hline 111 & $69 / 56$ & $53 / 38$ & $89 / 74$ & $75 / 67$ \\
\hline $11 \mathrm{~m}$ & $98 / 84$ & $48 / 40$ & $94 / 81$ & $72 / 75$ \\
\hline Cyhalofop & $77 / 46$ & $27 / 39$ & $95 / 66$ & $95 / 37$ \\
\hline
\end{tabular}

In conclusion, a series of new aryloxyphenoxypropionate derivatives containing a pyrimidine ring were designed and synthesized. The developed synthetic protocols are versatile and allow convenient functionalization of the phenoxypropionate core with various 2- or 4-pyrimidinyl moieties via the oxygen bridge, by taking advantage of the reactivity difference between 2methylsulfonyl and 4-chloro on the pyrimidine ring. The preliminary bioassay showed that most of the synthesized compounds had good herbicidal activities and were more potent to inhibit the 
stalk growth of barnyard grass with comparison to the commercial APP herbicide cyhalofop at low concentration. Further investigation on the enzyme activity of these compounds toward both the herbicide-sensitive and resistant forms of ACCase is in progress in this laboratory.

\section{Experimental Section}

\section{Docking study}

The molecular docking was performed and analyzed with the Autodock 4.2 program and the MGLTools 1.5.2 interface software. The CT domain model structure of ACCase was rebuilt from the crystal structure of yeast CT complex (PDB code: 1UYT) by extracting water molecules and diclofop. The active site was chosen as the docking center and the side chains of Tyr-1738 and Phe-1956' as flexible. The lead hit pyrimidinyloxyphenoxypropionic acid (IV) and haloxyfop (III) were docked into the active site. The lowest predicted binding energies and inhibition constants were obtained. The most favorable docked conformations were used for visualization and prediction of the binding energy and bioactivity. Meanwhile, diclofop (I) in the crystal state of the yeast CT complex was replaced into the active site for comparing the conformations.

\section{Chemistry}

General. All solvents were redistilled before use. Melting points were taken on a Buchi B-545 melting point apparatus and are uncorrected. IR were recorded on a PE-983 infrared spectrometer as $\mathrm{KBr}$ pellets with absorption in $\mathrm{cm}^{-1} .{ }^{1} \mathrm{H}$ NMR spectra were recorded on a Mercury-Plus 400 or Mercury-Plus 600 spectrometer in $\mathrm{CDCl}_{3}$ using TMS as an internal reference. MS were measured on a Finnigan Trace MS spectrometer, at $70 \mathrm{eV}$. Elemental analysis were taken on a Vario EL III elemental analyzer. The X-ray diffraction data were collected on a BrukerSMART AXS CCD diffractometer, MoKa, $2 \theta=2.80-27.00^{\circ}$. Unless otherwise noted, all materials were commercially available and were used directly without further purification.

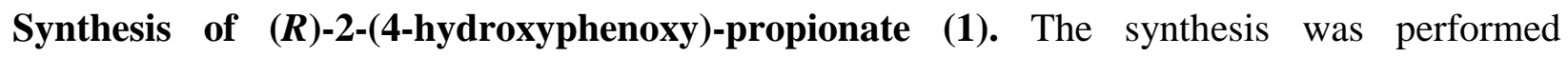
according to the reported method ${ }^{19}$ with some modification. Briefly, to a vigorously stirred solution of hydroquinone $(8.8 \mathrm{~g}, 80 \mathrm{mmol})$, sodium hydroxide $(9.6 \mathrm{~g}, 240 \mathrm{mmol})$ in methanol $(150 \mathrm{ml})$ at room temperature, $(S)$-2-(tosyloxy)propanoate $(60 \mathrm{mmol})$ was added dropwise. After $24 \mathrm{~h}$, the mixture was acidified with concentrated hydrochloric acid and heated at reflux for $2 \mathrm{~h}$. The solvent was evaporated in vacuum and the residue was dissolved in $100 \mathrm{ml}$ water, extracted with $\mathrm{CH}_{2} \mathrm{Cl}_{2}$. The Organic layer was dried with $\mathrm{Na}_{2} \mathrm{SO}_{4}$, the solvent was removed. The residue was purified by a silica gel column chromatography (petroleum ether-EtOAc) and give the corresponding $1(R)$-2-(4-hydroxyphenoxy)-propionate in high enantiomeric purity (>98\% ee, by HPLC analysis). 
Methyl (R)-2-(4-hydroxyphenoxy)propanoate. Yield 52\%, brown solid, mp $62-64{ }^{\circ} \mathrm{C}\left(\right.$ lit. $^{20} 64$ $\left.67^{\circ} \mathrm{C}\right)$.

Ethyl (R)-2-(4-hydroxyphenoxy)propanoate. Yield $66 \%$, colourless prisms, mp $36-37{ }^{\circ} \mathrm{C}\left(\right.$ lit. $^{20}$ $\left.35^{\circ} \mathrm{C}\right)$.

General procedure for the synthesis of 4-chloro-2-mercaptopyrimidines (5)

The synthesis was performed according to the reported method. ${ }^{21,22,23} \mathrm{~A}$ solution of thiourea 3 (3.8 g, $50 \mathrm{mmol})$, 1,3-dicarbonyl compound 2 (50 mmol) and sodium methoxide (6.5 g, 120 mmol) in methanol $(100 \mathrm{~mL})$ heated at reflux for $6 \mathrm{~h}$. The solvents were evaporated, and $\mathrm{H}_{2} \mathrm{O}$ $(150 \mathrm{~mL})$ was added. Dimethyl sulfate $(6.3 \mathrm{~g}, 50 \mathrm{mmol})$ was added dropwise with vigorous stirring and the reaction was stirred for $24 \mathrm{~h}$ at room temperature. Then the mixture was neutralized with concentrated $\mathrm{HCl}$ and the precipitate was collected. The solid was dried in vacuum and used directly to react with $\mathrm{POCl}_{3}(40 \mathrm{~mL})$ in the presence of $\mathrm{NEt}_{3}(5.05 \mathrm{~g}, 50 \mathrm{mmol})$ heated at $95-100{ }^{\circ} \mathrm{C}$ for $3 \mathrm{~h}$. Solvents were removed at reduced pressure, and the residue was poured into ice water and extracted with diethyl ether. The organic phase was washed with aqueous $\mathrm{NaHCO}_{3}$ and water, dried over $\mathrm{Na}_{2} \mathrm{SO}_{4}$. The solution was concentrated and the desired products 5 were obtained by recrystallization from the mixed solvent of EtOAc-petroleum ether.

4-Chloro-2-methylthio-6-trifluoromethylpyrimidine (5a). Yield 70\%, white solid, mp 38-39 ${ }^{\circ} \mathrm{C} .{ }^{1} \mathrm{H}$ NMR $\left(600 \mathrm{MHz} \mathrm{CDCl}_{3}\right), \delta 2.55\left(\mathrm{~s}, 3 \mathrm{H}, \mathrm{SCH}_{3}\right), 6.66(\mathrm{~s}, 1 \mathrm{H}$, pyrimidine-H). $\mathrm{MS}(\mathrm{m} / z, \%)$ : $228\left(\mathrm{M}^{+}, 36\right), 193$ (100), 124 (41). Anal. Calcd for $\mathrm{C}_{6} \mathrm{H}_{4} \mathrm{ClF}_{3} \mathrm{~N}_{2} \mathrm{~S}: \mathrm{C}, 31.52 ; \mathrm{H}, 1.76 ; \mathrm{N}, 12.25 \%$. Found: C, 31.74; H, 1.82; N, $11.97 \%$.

4-Chloro-6-methyl-2-methylthiopyrimidine (5b). Yield $76 \%$, white solid, mp $41-42{ }^{\circ} \mathrm{C}$ (lit. $^{24}$ mp 39-40 $\left.{ }^{\circ} \mathrm{C}\right)$.

4-Chloro-5,6-dimethyl-2-methylthiopyrimidine (5c). Yield 78\%, colourless prisms, mp 33-34 ${ }^{\circ} \mathrm{C} .{ }^{1} \mathrm{H}$ NMR (600 MHz, $\left.\mathrm{CDCl}_{3}\right), \delta 2.46\left(\mathrm{~s}, 3 \mathrm{H}\right.$, pyrimidine- $\left.\mathrm{CH}_{3}\right), 2.56\left(\mathrm{~s}, 3 \mathrm{H}, \mathrm{SCH}_{3}\right), 2.68(\mathrm{~s}$, $3 \mathrm{H}$, pyrimidine- $\left.\mathrm{CH}_{3}\right)$. MS ( $\left.\mathrm{m} / \mathrm{z}, \%\right): 188\left(\mathrm{M}^{+}, 52\right), 153$ (66), 91 (78). Anal. Calcd for $\mathrm{C}_{7} \mathrm{H}_{9} \mathrm{ClN}_{2} \mathrm{~S}$ : C, 44.56; H, 4.81; N, 14.85\%. Found: C, 44.25; H, 4.98; N, 14.69\%.

4-Chloro-5-ethyl-6-methyl-2-methylthiopyrimidine (5d). Yield 72\%, colourless prisms, mp 36-37 ${ }^{\circ} \mathrm{C} .{ }^{1} \mathrm{H}$ NMR (600 MHz, $\left.\mathrm{CDCl}_{3}\right), \delta 1.46\left(\mathrm{t}, 3 \mathrm{H}, J=6.6 \mathrm{~Hz}, \mathrm{CH}_{2} \mathrm{CH}_{3}\right), 2.38$ (s, 3H, pyrimidine- $\left.\mathrm{CH}_{3}\right), 2.56$ (s, 3H, $\left.\mathrm{SCH}_{3}\right), 2.65$ (q, 3H, $\left.J=6.6 \mathrm{~Hz}, \mathrm{CH}_{2}\right) . \mathrm{MS}(\mathrm{m} / z, \%): 202\left(\mathrm{M}^{+}, 22\right)$, 167 (59), 120 (100). Anal. Calcd for $\mathrm{C}_{8} \mathrm{H}_{11} \mathrm{ClN}_{2} \mathrm{~S}$ : C, 47.40; H, 5.47; N, 13.82\%. Found: C, 47.16; H, 5.62; N, 13.97\%.

4-Chloro-2-methylthio-6-phenylpyrimidine (5e). Yield $75 \%$, white solid, mp $37-38{ }^{\circ} \mathrm{C}$ (lit. ${ }^{25}$ mp $\left.35-36{ }^{\circ} \mathrm{C}\right)$.

4,6-Dichloro-2-methylthiopyrimidine (5f). Yield 72\%, colourless prisms, mp $42-43{ }^{\circ} \mathrm{C}$ (lit. ${ }^{26}$ mp 40-41 $\left.{ }^{\circ} \mathrm{C}\right)$.

4,6-Dichloro-5-ethyl-2-methylthiopyrimidine (5g). Yield 78\%, colourless prisms, mp 58-59 ${ }^{\circ} \mathrm{C} .{ }^{1} \mathrm{H}$ NMR $\left(600 \mathrm{MHz}, \mathrm{CDCl}_{3}\right), \delta 1.45\left(\mathrm{t}, 3 \mathrm{H}, J=6.8 \mathrm{~Hz}, \mathrm{CH}_{2} \mathrm{CH}_{3}\right), 2.56\left(\mathrm{~s}, 3 \mathrm{H}, \mathrm{SCH}_{3}\right), 2.65$ (q, 3H, $\left.J=6.8 \mathrm{~Hz}, \mathrm{CH}_{2}\right)$. MS (m/z, \%): $223\left(\mathrm{M}^{+}, 17\right), 187$ (69), 123 (100). Anal. Calcd for $\mathrm{C}_{7} \mathrm{H}_{8} \mathrm{Cl}_{2} \mathrm{~N}_{2} \mathrm{~S}: \mathrm{C}, 37.68 ; \mathrm{H}, 3.61 ; \mathrm{N}, 12.56 \%$. Found: $\mathrm{C}, 37.84 ; \mathrm{H}, 3.56 ; \mathrm{N}, 12.71 \%$. 
4,6-Dichloro-2-(methylthio)-5-nitropyrimidine (5h). Yield 72\%, pale yellow prisms, mp 56-57 ${ }^{\circ} \mathrm{C}$ (lit. ${ }^{27} \mathrm{mp} 61{ }^{\circ} \mathrm{C}$ ).

\section{General procedure for the synthesis of 2-methylsulfonylpyrimidines (9)}

The synthesis was performed according to the reported method. ${ }^{18} 2$-methylthiopyrimidine 5 or 6 (10 mmol) was dissolved in dichloromethane $(20 \mathrm{~mL})$ and a solution of $m$-CPBA $(25 \mathrm{mmol})$ in $\mathrm{CH}_{2} \mathrm{Cl}_{2}(40 \mathrm{~mL})$ was added dropwise at room temperature. After stirring for $10 \mathrm{~h}$, the reaction mixture was washed sequentially with saturated $\mathrm{NaHSO}_{3}$, saturated $\mathrm{Na}_{2} \mathrm{CO}_{3}$, brine, and dried over anhydrous $\mathrm{MgSO}_{4}$. Concentration in vacuum gave 2-methylsulfonylpyrimidine 9.

4-Chloro-2-methylsulfonyl-6-trifluoromethylpyrimidine (9a). Yield 81\%, pale yellow prisms, mp 81-82 ${ }^{\circ} \mathrm{C} .{ }^{1} \mathrm{H}$ NMR (600 MHz, $\mathrm{CDCl}_{3}$ ), $\delta 3.34$ (s, 3H, $\mathrm{SO}_{2} \mathrm{CH}_{3}$ ), 6.67 (s, 1H, pyrimidine-H). MS (m/z, \%): $260\left(\mathrm{M}^{+}, 28\right), 181$ (62), 146 (100). Anal. Calcd for $\mathrm{C}_{6} \mathrm{H}_{4} \mathrm{ClF}_{3} \mathrm{~N}_{2} \mathrm{O}_{2} \mathrm{~S}: \mathrm{C}, 27.65 ; \mathrm{H}$, $1.55 ; \mathrm{N}, 10.75 \%$. Found: C, 27.93; H, 1.58; N, 11.02\%.

4-Chloro-6-methyl-2-methylsulfonylpyrimidine (9b). Yield 81\%, colourless prisms, mp 244$245{ }^{\circ} \mathrm{C} .{ }^{1} \mathrm{H}$ NMR $\left(600 \mathrm{MHz}, \mathrm{CDCl}_{3}\right), \delta 2.43\left(\mathrm{~s}, 3 \mathrm{H}\right.$, pyrimidine- $\left.\mathrm{CH}_{3}\right), 3.38\left(\mathrm{~s}, 3 \mathrm{H}, \mathrm{SO}_{2} \mathrm{CH}_{3}\right)$, 6.72 (s, 1H, pyrimidine-H). MS (m/z, \%): $206\left(\mathrm{M}^{+}, 11\right), 171$ (46), 127 (45), 92 (100). Anal. Calcd for $\mathrm{C}_{6} \mathrm{H}_{7} \mathrm{ClN}_{2} \mathrm{O}_{2} \mathrm{~S}: \mathrm{C}, 34.87 ; \mathrm{H}, 3.41 ; \mathrm{N}, 13.56 \%$. Found: C, 34.90; H, 3.76; N, $13.45 \%$.

4-Chloro-5,6-dimethyl-2-methylsulfonylpyrimidine (9c). Yield 85\%, white solid, mp 185-186 ${ }^{\circ} \mathrm{C}$. ${ }^{1} \mathrm{H}$ NMR $\left(600 \mathrm{MHz}, \mathrm{CDCl}_{3}\right), \delta 2.46(\mathrm{~s}, 3 \mathrm{H}$, pyrimidine-CH$), 2.67$ (s, 3H, CH 3$), 3.34(\mathrm{~s}, 3 \mathrm{H}$, $\left.\mathrm{SO}_{2} \mathrm{CH}_{3}\right)$. MS (m/z, \%): $220\left(\mathrm{M}^{+}, 19\right), 185$ (59), 141 (100), 106 (74). Anal. Calcd for $\mathrm{C}_{7} \mathrm{H}_{9} \mathrm{ClN}_{2} \mathrm{O}_{2} \mathrm{~S}: \mathrm{C}, 38.10 ; \mathrm{H}, 4.11 ; \mathrm{N}, 12.69 \%$. Found: C, 38.23; H, 4.21; N, $12.56 \%$.

4-Chloro-5-ethyl-6-methyl-2-methylsulfonylpyrimidine (9d). Yield 80\%, colourless prisms, mp 171-172 ${ }^{\circ} \mathrm{C} .{ }^{1} \mathrm{H}$ NMR (600 MHz, $\left.\mathrm{CDCl}_{3}\right), \delta 1.42\left(\mathrm{t}, 3 \mathrm{H}, J=6.8 \mathrm{~Hz}, \mathrm{CH}_{2} \underline{\mathrm{CH}_{3}}\right), 2.38$ (s, 3H, pyrimidine- $\left.\mathrm{CH}_{3}\right), 2.68$ (q, 3H, $\left.J=6.8 \mathrm{~Hz}, \mathrm{CH}_{2}\right), 3.38\left(\mathrm{~s}, 3 \mathrm{H}, \mathrm{SO}_{2} \mathrm{CH}_{3}\right) . \mathrm{MS}(\mathrm{m} / \mathrm{z}, \%)$ : $234\left(\mathrm{M}^{+}\right.$, 24), 199 (62), 155 (100), 120 (46). Anal. Calcd for $\mathrm{C}_{8} \mathrm{H}_{11} \mathrm{ClN}_{2} \mathrm{O}_{2} \mathrm{~S}: \mathrm{C}, 40.94 ; \mathrm{H}, 4.72 ; \mathrm{N}, 11.94 \%$. Found: C, 40.82; H, 4.66; N, $12.31 \%$.

4-Chloro-2-methylsulfonyl-6-phenylpyrimidine (9e). Yield 82\%, white solid, mp $149-150{ }^{\circ} \mathrm{C}$. ${ }^{1} \mathrm{H}$ NMR (600 MHz, $\mathrm{CDCl}_{3}$ ), $\delta 3.34\left(\mathrm{~s}, 3 \mathrm{H}, \mathrm{SO}_{2} \mathrm{CH}_{3}\right), 6.80(\mathrm{~s}, 1 \mathrm{H}$, pyrimidine- $\mathrm{H}), 7.80-7.42(\mathrm{~m}$, 5H, ArH). MS (m/z, \%): $269\left(\mathrm{M}^{+}, 32\right), 233$ (52), 189 (65), 154 (100). Anal. Calcd for $\mathrm{C}_{11} \mathrm{H}_{9} \mathrm{ClN}_{2} \mathrm{O}_{2} \mathrm{~S}: \mathrm{C}, 49.17$; H, 3.38; N, 10.42\%. Found: C, 49.38; H, 3.24; N, 10.16\%.

4,6-Dichloro-2-methylsulfonylpyrimidine (9f). Yield $80 \%$, colourless prisms, mp $132-133{ }^{\circ} \mathrm{C}$, (lit. ${ }^{28} \mathrm{mp} 154-156^{\circ} \mathrm{C}$ ).

4,6-Dichloro-5-ethyl-2-methylsulfonylpyrimidine (9g). Yield 85\%, colourless prisms, mp 124$125{ }^{\circ} \mathrm{C} .{ }^{1} \mathrm{H}$ NMR $\left(600 \mathrm{MHz}, \mathrm{CDCl}_{3}\right), \delta 2.68\left(\mathrm{t}, 2 \mathrm{H}, J=6.8 \mathrm{~Hz}, \mathrm{CH}_{2}\right), 3.38\left(\mathrm{~s}, 3 \mathrm{H}, \mathrm{SO}_{2} \mathrm{CH}_{3}\right), 1.62$ (q, 3H, $\left.J=6.8 \mathrm{~Hz}, \mathrm{CH}_{2}\right)$. MS ( $\left.\mathrm{m} / \mathrm{z}, \%\right): 255\left(\mathrm{M}^{+}, 25\right), 219$ (61), 184 (56), 140 (100). Anal. Calcd for $\mathrm{C}_{7} \mathrm{H}_{8} \mathrm{Cl}_{2} \mathrm{~N}_{2} \mathrm{O}_{2} \mathrm{~S}$ : C, 32.95; H, 3.16; N, 10.98\%. Found: C, 32.69; H, 3.26; N, $11.05 \%$.

4,6-Dichloro-2-methylsulfonyl-5-nitropyrimidine (9h). Yield 81\%, pale yellow prisms, mp 76$77{ }^{\circ} \mathrm{C} .{ }^{1} \mathrm{H}$ NMR $\left(600 \mathrm{MHz}, \mathrm{CDCl}_{3}\right), \delta 3.35$ (s, 3H, $\left.\mathrm{SO}_{2} \mathrm{CH}_{3}\right)$. MS (m/z, \%): $272\left(\mathrm{M}^{+}, 16\right), 236$ (63), 200 (100), 122 (76). Anal. Calcd for $\mathrm{C}_{5} \mathrm{H}_{3} \mathrm{Cl}_{2} \mathrm{~N}_{3} \mathrm{O}_{4} \mathrm{~S}$ : C, 22.07; H, 1.11; N, 15.44\%. Found: C, $22.39 ; \mathrm{H}, 1.16 ; \mathrm{N}, 15.27 \%$. 
General procedure for the synthesis of $(R)-2-(4-(p y r i m i d i n-2-y l o x y) p h e n o x y) p r o p a n o a t e s$

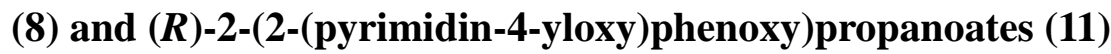

The synthesis was performed according to the reported method ${ }^{29}$ with some modification. Briefly, a solution of (R)-2-(4-hydroxy-phenoxy)-propanoate $1(10 \mathrm{mmol})$, anhydrous $\mathrm{K}_{2} \mathrm{CO}_{3}$ (2.5 equiv, $25 \mathrm{mmol}$ ) in $\mathrm{CH}_{3} \mathrm{CN}(50 \mathrm{ml})$ was stirred at room temperature for $0.5 \mathrm{~h}$. After another $0.5 \mathrm{~h}$ of reflux, the solution of 4-chloropyrimidine $\mathbf{5}, \mathbf{1 0}(10 \mathrm{mmol})$ or 2-methylsulfonyl pyrimidine 7, $9(10 \mathrm{mmol})$ in $\mathrm{CH}_{3} \mathrm{CN}(20 \mathrm{ml})$ was added dropwise and the mixture heated at reflux for another $4 \mathrm{~h}$. After evaporation of the solvent, water was added and the mixture was extracted with ethyl acetate and the organic phase was dried over $\mathrm{MgSO}_{4}$. The products 8 or 11 were purification by flash chromatography on silica gel.

Methyl (R)-2-(4-(4-chloro-6-trifluoromethylpyrimidin-2-yloxy)phenoxy)propanoate (8a). Yield 65\%, white solid, mp 98-100 ${ }^{\circ} \mathrm{C}$. ${ }^{1} \mathrm{H} \mathrm{NMR}\left(600 \mathrm{MHz}, \mathrm{CDCl}_{3}\right), \delta 1.63(\mathrm{~d}, 3 \mathrm{H}, J=6.6 \mathrm{~Hz}$, $\left.\mathrm{CHCH}_{3}\right) 3.79\left(\mathrm{~s}, 3 \mathrm{H}, \underline{\mathrm{OCH}}_{3}\right), 4.74(\mathrm{q}, J=6.6 \mathrm{~Hz}, 1 \mathrm{H}, \mathrm{CH}), 6.47(1 \mathrm{H}, \mathrm{s}$, pyrimidine-H), 6.89 (d, $J$ $=7.2 \mathrm{~Hz}, 2 \mathrm{H}, \mathrm{ArH}), 7.06$ (d, $J=7.8 \mathrm{~Hz}, 2 \mathrm{H}, \mathrm{ArH}), \mathrm{IR}(\mathrm{KBr}) v: 1743,1678,1504,1352,1211$ $\mathrm{cm}^{-1}$. MS (m/z, \%): $376\left(\mathrm{M}^{+}, 21\right), 376$ (34), 341 (28). Anal. Calcd for $\mathrm{C}_{15} \mathrm{H}_{12} \mathrm{ClF}_{3} \mathrm{~N}_{2} \mathrm{O}_{4}: \mathrm{C}, 47.82$; H, 3.21; N, 7.44\%. Found: C, 48.13; H, 3.19; N, 7.80\%.

Methyl (R)-2-(4-(4-chloro-6-methylpyrimidin-2-yloxy)phenoxy)propanoate (8b). Yield 45\%, white solid, mp 39-40 ${ }^{\circ} \mathrm{C} .{ }^{1} \mathrm{H}$ NMR $\left(600 \mathrm{MHz} \mathrm{CDCl}_{3}\right), \delta 1.63\left(\mathrm{~d}, J=6.8 \mathrm{~Hz}, 3 \mathrm{H}, \mathrm{CHCH}_{3}\right), 2.54$ $\left(\mathrm{s}, 3 \mathrm{H}\right.$, pyrimidine- $\left.\mathrm{CH}_{3}\right), 3.77\left(\mathrm{~s}, 3 \mathrm{H}, \mathrm{OCH}_{3}\right), 4.75(\mathrm{q}, J=6.8 \mathrm{~Hz}, 1 \mathrm{H}, \mathrm{CH}), 6.28(\mathrm{~s}, 1 \mathrm{H}$, pyrimidine-H), 6.89 (d, $J=9.0 \mathrm{~Hz}, 2 \mathrm{H}, \mathrm{ArH}), 7.12(\mathrm{~d}, J=9.0 \mathrm{~Hz}, 2 \mathrm{H}, \mathrm{ArH}) . \mathrm{IR}(\mathrm{KBr}) v: 3438$, 1757, 1599, $1206 \mathrm{~cm}^{-1}$. MS (m/z, \%): $322\left(\mathrm{M}^{+}, 65\right), 287$ (100), 235 (50). Anal. Calcd for $\mathrm{C}_{15} \mathrm{H}_{15} \mathrm{ClN}_{2} \mathrm{O}_{4}$ : C, 55.82; H, 4.68; N, 8.68\%. Found: C, 55.76; H, 4.71; N, 8.95\%.

Ethyl $(\boldsymbol{R})$-2-(4-(4,6-dichloropyrimidin-2-yloxy)phenoxy)propanoate $(\mathbf{8 c})$. Yield 58\%, colourless needles, mp 64-65 ${ }^{\circ} \mathrm{C} .{ }^{1} \mathrm{H}$ NMR $\left(400 \mathrm{MHz}, \mathrm{CDCl}_{3}\right), \delta 1.27(\mathrm{t}, J=7.2 \mathrm{~Hz}, 3 \mathrm{H}$, $\left.\mathrm{CH}_{2} \underline{\mathrm{CH}}_{3}\right), 1.64\left(\mathrm{~d}, J=4.9 \mathrm{~Hz}, 3 \mathrm{H}, \mathrm{CH}_{\underline{\mathrm{CH}}}\right), 4.24$ (q, $\left.J=4.9 \mathrm{~Hz}, 2 \mathrm{H}, \mathrm{CH}_{2}\right), 4.74$ (q, J = 6.8 Hz, $1 \mathrm{H}, \mathrm{CH}), 6.80(\mathrm{~s}, 1 \mathrm{H}$, pyrimidine-H), $6.91(\mathrm{~d}, J=9.2 \mathrm{~Hz}, 2 \mathrm{H}, \mathrm{ArH}), 7.11(\mathrm{~d}, J=8.8 \mathrm{~Hz}, 2 \mathrm{H}$, ArH). IR (KBr) v: 3116, 2922, 1747, 1265, 1240, 1190, $771 \mathrm{~cm}^{-1} . \mathrm{MS}(\mathrm{m} / z, \%): 356\left(\mathrm{M}^{+}, 25\right)$, 321 (26), 310 (100), 283 (24), 237 (69). Anal. Calcd for $\mathrm{C}_{15} \mathrm{H}_{14} \mathrm{Cl}_{2} \mathrm{~N}_{2} \mathrm{O}_{4}$ : C, 50.44; $\mathrm{H}, 3.95 ; \mathrm{N}$, 7.84\%. Found: C, 50.05; H, 3.81; N, 7.98\%.

Ethyl $(R)$-2-(4-(4,6-dichloro-5-ethylpyrimidin-2-yloxy)phenoxy)propanoate (8d). Yield 65\%, white solid, mp 43-44 ${ }^{\circ} \mathrm{C} .{ }^{1} \mathrm{H} \mathrm{NMR}\left(400 \mathrm{MHz}, \mathrm{CDCl}_{3}\right), \delta 1.19$ (t, $J=7.6 \mathrm{~Hz}, 3 \mathrm{H}$, pyrimidine$\left.\mathrm{CH}_{2} \underline{\mathrm{CH}}_{3}\right), 1.27$ (t, $\left.J=7.2 \mathrm{~Hz}, 3 \mathrm{H}, \mathrm{OCH}_{2} \underline{\mathrm{CH}}_{3}\right), 1.63\left(\mathrm{~d}, J=4.9 \mathrm{~Hz}, 3 \mathrm{H}, \mathrm{CHCH}_{3}\right), 2.84(\mathrm{q}, J=7.6$ $\mathrm{Hz}, 2 \mathrm{H}$, pyrimidine- $\left.\mathrm{CH}_{2} \mathrm{CH}_{3}\right), 4.23\left(\mathrm{q}, J=4.9 \mathrm{~Hz}, 2 \mathrm{H}, \mathrm{OCH}_{2} \mathrm{CH}_{3}\right), 4.73(\mathrm{q}, J=6.8 \mathrm{~Hz}, 1 \mathrm{H}, \mathrm{CH})$, $6.90(\mathrm{~d}, J=8.8 \mathrm{~Hz}, 2 \mathrm{H}, \mathrm{ArH}), 7.08$ (d, $J=8.8 \mathrm{~Hz}, 2 \mathrm{H}, \mathrm{ArH}) . \mathrm{IR}(\mathrm{KBr})$ v: 2981, 1753, 1398, 1191, $820 \mathrm{~cm}^{-1}$. MS (m/z, \%): $384\left(\mathrm{M}^{+}, 100\right), 349$ (62), 249 (23). Anal. Calcd for $\mathrm{C}_{17} \mathrm{H}_{18} \mathrm{Cl}_{2} \mathrm{~N}_{2} \mathrm{O}_{4}$ : C, 53.00; H, 4.71; N, 7.27\%. Found: C, 53.28; H, 4.96; N, 7.10\%.

Methyl (R)-2-(4-(4,6-dichloro-5-nitropyrimidin-2-yloxy)phenoxy)propanoate (8e). Yield $50 \%$, pale yellow prisms, mp 80-81 ${ }^{\circ} \mathrm{C} .{ }^{1} \mathrm{H} \mathrm{NMR}\left(600 \mathrm{MHz}, \mathrm{CDCl}_{3}\right), \delta 1.64(\mathrm{~d}, J=6.6 \mathrm{~Hz}, 3 \mathrm{H}$, $\left.\mathrm{CHCH}_{3}\right), 3.94\left(\mathrm{~s}, 3 \mathrm{H}, \underline{\mathrm{OCH}}_{3}\right), 4.75(\mathrm{q}, J=6.6 \mathrm{~Hz}, 1 \mathrm{H}, \mathrm{CH}), 6.90(\mathrm{~d}, J=9.0 \mathrm{~Hz}, 2 \mathrm{H}, \mathrm{ArH}), 7.08$ 
$(\mathrm{d}, J=9.0 \mathrm{~Hz}, 2 \mathrm{H}, \mathrm{ArH})$; IR (KBr) v: 3442, 1740, 1581, $1195 \mathrm{~cm}^{-1} . \mathrm{MS}(\mathrm{m} / \mathrm{z}, \%): 388\left(\mathrm{M}^{+}, 76\right)$, 301 (84), 192 (65). Anal. Calcd for $\mathrm{C}_{14} \mathrm{H}_{11} \mathrm{C}_{12} \mathrm{~N}_{3} \mathrm{O}_{6}$ : C, 43.32; H, 2.86; N, 10.83\%. Found: C, 43.80; H, 2.94; N, $11.15 \%$.

Methyl (R)-2-(4-(4-methoxy-6-trifluoromethylpyrimidin-2-yloxy)phenoxy)propanoate (8f). Yield 67\%, white solid, mp 137-138 ${ }^{\circ} \mathrm{C} .{ }^{1} \mathrm{H}$ NMR (600 MHz, $\left.\mathrm{CDCl}_{3}\right), \delta 1.64(\mathrm{~d}, J=6.6 \mathrm{~Hz}, 3 \mathrm{H}$, $\left.\mathrm{CHCH}_{3}\right), 3.79$ (s, 3H, $\left.\underline{\mathrm{OCH}}_{3}\right), 3.90$ (s, 3H, pyrimidine- $\left.\underline{\mathrm{OCH}}_{3}\right), 4.77$ (q, J=6.6 Hz, 1H, CH), 6.76 (s, 1H, pyrimidine-H), $6.90(\mathrm{~d}, J=7.8 \mathrm{~Hz}, 2 \mathrm{H}, \mathrm{ArH}), 7.13(\mathrm{~d}, J=7.8 \mathrm{~Hz}, 2 \mathrm{H}, \mathrm{ArH}) . \mathrm{IR}(\mathrm{KBr}) \mathrm{v}$ : 1758, 1611, 1504, 1370, $1294 \mathrm{~cm}^{-1}$. MS (m/z, \%): $372\left(\mathrm{M}^{+}, 12\right), 284$ (12), 216 (10). Anal. Calcd for $\mathrm{C}_{16} \mathrm{H}_{15} \mathrm{~F}_{3} \mathrm{~N}_{2} \mathrm{O}_{5}$ : C, 51.62; H, 4.06; N, 7.52\%. Found: C, 52.05; H, 4.27; N, 7.98\%.

Methyl $(R)$-2-(4-(4-ethoxy-6-trifluoromethylpyrimidin-2-yloxy)phenoxy)propanoate (8g). Yield 70\%, white solid, mp 140-141 ${ }^{\circ} \mathrm{C} .{ }^{1} \mathrm{H}$ NMR (600 MHz, $\mathrm{CDCl}_{3}$ ), $\delta 1.33$ (t, $J=6.8 \mathrm{~Hz}, 3 \mathrm{H}$, $\left.\mathrm{CH}_{2} \underline{\mathrm{CH}}_{3}\right), 1.64$ (d, $\left.J=6.8 \mathrm{~Hz}, 3 \mathrm{H}, \mathrm{CHCH}_{3}\right), 3.78\left(\mathrm{~s}, 3 \mathrm{H}, \underline{\mathrm{OCH}_{3}}\right), 4.32$ (q, $J=7.0 \mathrm{~Hz}, 2 \mathrm{H}$, $\left.\mathrm{CH}_{2} \mathrm{CH}_{3}\right), 4.77(\mathrm{q}, J=6.8 \mathrm{~Hz}, 1 \mathrm{H}, \mathrm{CH}), 6.76(\mathrm{~s}, 1 \mathrm{H}$, pyrimidine-H), $6.90(\mathrm{~d}, J=7.2 \mathrm{~Hz}, 2 \mathrm{H}$, ArH), 7.11 (d, J=7.2 Hz, 2H, ArH); IR (KBr) v: 1759, 1605, 1504, 1375, $1201 \mathrm{~cm}^{-1}$. MS (m/z, \%): $386\left(\mathrm{M}^{+}, 10\right), 321$ (13), 228 (22). Anal. Calcd for $\mathrm{C}_{17} \mathrm{H}_{17} \mathrm{~F}_{3} \mathrm{~N}_{2} \mathrm{O}_{5}: \mathrm{C}, 52.85 ; \mathrm{H}, 4.44 ; \mathrm{N}$, 7.25\%. Found: C, 52.60; H, 4.36; N, 7.53\%.

Methyl $(R)$-2-(4-(4-methylamino-6-trifluoromethylpyrimidin-2-yloxy)phenoxy)propanoate (8h). Yield 55\%, white solid, mp 95-97 ${ }^{\circ} \mathrm{C} .{ }^{1} \mathrm{H} \mathrm{NMR}\left(600 \mathrm{MHz}, \mathrm{CDCl}_{3}\right), \delta 1.63(\mathrm{~d}, J=6.8 \mathrm{~Hz}$, $\left.3 \mathrm{H}, \mathrm{CHCH}_{3}\right), 2.93\left(\mathrm{~d}, J=4.2 \mathrm{~Hz}, 3 \mathrm{H}, \mathrm{NHCH}_{3}\right), 3.78\left(\mathrm{~s}, 3 \mathrm{H}, \underline{\mathrm{OCH}}_{3}\right), 4.75$ (q, $J=6.8 \mathrm{~Hz}, 1 \mathrm{H}$, $\mathrm{CH}), 5.35(\mathrm{~s}, 1 \mathrm{H}, \mathrm{NH}), 6.38(\mathrm{~s}, 1 \mathrm{H}$, pyrimidine-H), $6.87(\mathrm{~d}, J=8.4 \mathrm{~Hz}, 2 \mathrm{H}, \mathrm{ArH}), 7.10(\mathrm{~d}, J=$ $8.4 \mathrm{~Hz}, 2 \mathrm{H}, \mathrm{ArH})$. IR (KBr) v: 1745, 1619, 1506, 1370, $1185 \mathrm{~cm}^{-1}$. MS (m/z, \%): $371\left(\mathrm{M}^{+}, 10\right)$, 282 (34). Anal. Calcd for $\mathrm{C}_{17} \mathrm{H}_{17} \mathrm{~F}_{3} \mathrm{~N}_{2} \mathrm{O}_{5}$ : C, 51.75; H, 4.34; N, 11.32\%. Found: C, 52.89; H, $4.29 ; \mathrm{N}, 11.49 \%$.

Methyl (R)-2-(4-(4-methyl-6-trifluoromethylpyrimidin-2-yloxy)phenoxy)propanoate (8i). Yield 49\%, slight yellow solid, mp 40-41 ${ }^{\circ} \mathrm{C} .{ }^{1} \mathrm{H}$ NMR $\left(600 \mathrm{MHz}, \mathrm{CDCl}_{3}\right), \delta 1.63(\mathrm{~d}, J=6.6 \mathrm{~Hz}$, $\left.3 \mathrm{H}, \mathrm{CHCH}_{3}\right), 3.79$ (s, $3 \mathrm{H}$, pyrimidine- $\left.\underline{\mathrm{CH}}_{3}\right), 3.78\left(\mathrm{~s}, 3 \mathrm{H}, \mathrm{OCH}_{3}\right), 4.77(\mathrm{q}, J=6.6 \mathrm{~Hz}, 1 \mathrm{H}, \mathrm{CH})$, 6.90 (d, $J=7.2 \mathrm{~Hz}, 2 \mathrm{H}, \operatorname{ArH}), 7.12$ (d, $J=7.2 \mathrm{~Hz}, 2 \mathrm{H}, \mathrm{ArH}), 7.21$ (s, 1H, pyrimidine-H). IR (KBr) v: 1757, 1600, 1504, 1367, $1200 \mathrm{~cm}^{-1}$. MS (m/z, \%): $356\left(\mathrm{M}^{+}, 21\right), 346$ (34), 311 (28); Anal. Calcd for $\mathrm{C}_{16} \mathrm{H}_{15} \mathrm{~F}_{3} \mathrm{~N}_{2} \mathrm{O}_{4}$ : C, 53.94; H, 4.24; N, 7.86\%. Found: C, 53.78; H, 4.49; N, $7.98 \%$.

Methyl (R)-2-(4-(4-methoxy-6-methylpyrimidin-2-yloxy)phenoxy)propanoate (8j). Yield $70 \%$, colourless needles, mp 43-44 ${ }^{\circ} \mathrm{C} .{ }^{1} \mathrm{H}$ NMR (400 MHz, $\left.\mathrm{CDCl}_{3}\right), \delta 1.63(\mathrm{~d}, J=6.8 \mathrm{~Hz}, 3 \mathrm{H}$, $\left.\mathrm{CHCH}_{3}\right), 3.77$ (s, 3H, OCH 3$), 3.88$ (s, 3H, pyrimidine- $\left.\underline{\mathrm{OCH}}_{3}\right), 4.75$ (q, J=6.8 Hz, 1H, CH), 6.47 (s, 1H, pyrimidine-H), 6.89 (d, $J=9.2 \mathrm{~Hz}, 2 \mathrm{H}, \mathrm{ArH}), 7.10(\mathrm{~d}, J=8.8 \mathrm{~Hz}, 2 \mathrm{H}, \mathrm{ArH}) . \mathrm{IR}(\mathrm{KBr}) \mathrm{v}$ : 3438, 1757, 1599, 1504, $1352 \mathrm{~cm}^{-1}$. MS (m/z, \%): $318\left(\mathrm{M}^{+}, 21\right), 231$ (70), 195 (66). Anal. Calcd for $\mathrm{C}_{16} \mathrm{H}_{18} \mathrm{~N}_{2} \mathrm{O}_{5}$ : C, 60.37; H, 5.70; N, 8.80\%. Found: C, 6.75; H, 5.42; N, 8.92\%.

Methyl $(R)$-2-(4-(4-methyl-6-methylaminopyrimidin-2-yloxy)phenoxy)propanoate (8k). Yield 65\%, white solid, mp 90-91 ${ }^{\circ} \mathrm{C} .{ }^{1} \mathrm{H}$ NMR (400 MHz, $\mathrm{CDCl}_{3}$ ), $\delta 1.63$ (d, $J=6.8 \mathrm{~Hz}, 3 \mathrm{H}$, $\left.\mathrm{CHCH}_{3}\right), 2.89\left(\mathrm{~d}, J=4.8 \mathrm{~Hz}, 3 \mathrm{H}, \mathrm{NHCH}_{3}\right), 3.78\left(\mathrm{~s}, 3 \mathrm{H}, \mathrm{OCH}_{3}\right), 4.74(\mathrm{q}, J=6.8 \mathrm{~Hz}, 1 \mathrm{H}, \mathrm{CH})$, $5.44(\mathrm{~s}, 1 \mathrm{H}, \underline{\mathrm{NH}}), 6.07(\mathrm{~s}, 1 \mathrm{H}$, pyrimidine-H), $6.86(\mathrm{~d}, J=9.2 \mathrm{~Hz}, 2 \mathrm{H}, \mathrm{ArH}), 7.08(\mathrm{~d}, J=8.8 \mathrm{~Hz}$, 
2H, ArH). IR (KBr) v: 3283, 1753, 1581, 1503, $1352 \mathrm{~cm}^{-1} . \mathrm{MS}(\mathrm{m} / \mathrm{z}, \%): 337\left(\mathrm{M}^{+}, 31\right), 299$ (100), 138 (21). Anal. Calcd for $\mathrm{C}_{16} \mathrm{H}_{19} \mathrm{~N}_{3} \mathrm{O}_{4}$ : C, 60.56; H, 6.03; N, 13.24\%. Found: C, 60.32; H, 6.32; $\mathrm{N}, 12.87 \%$.

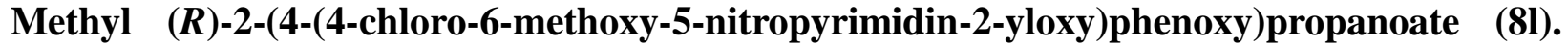
Yield 54\%, colourless prisms, mp 92-93 ${ }^{\circ} \mathrm{C} .{ }^{1} \mathrm{H}$ NMR $\left(600 \mathrm{MHz}, \mathrm{CDCl}_{3}\right), \delta 1.63(\mathrm{~d}, J=6.6 \mathrm{~Hz}$,

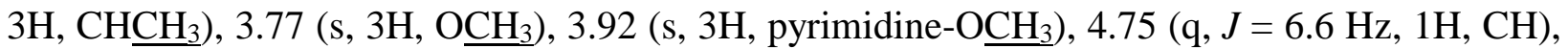
$6.90(\mathrm{~d}, J=9.0 \mathrm{~Hz}, 2 \mathrm{H}, \mathrm{ArH}), 7.08(\mathrm{~d}, J=9.0 \mathrm{~Hz}, 2 \mathrm{H}, \mathrm{ArH}) . \mathrm{IR}(\mathrm{KBr}) v: 3430,1750,1576,1218$ $\mathrm{cm}^{-1}$. MS (m/z,\%): $383\left(\mathrm{M}^{+}, 62\right), 296$ (96), 204 (38). Anal. Calcd for $\mathrm{C}_{15} \mathrm{H}_{14} \mathrm{ClN}_{3} \mathrm{O}_{7}: \mathrm{C}, 46.95$; H, 3.68; N, 10.95\%. Found: C, 46.65; H, 3.49; N, $10.63 \%$.

Ethyl (R)-2-(4-(4,6-dimethoxypyrimidin-2-yloxy)phenoxy)propanoate (8m). Yield 67\%, white solid, mp 77-78 ${ }^{\circ} \mathrm{C}$. ${ }^{1} \mathrm{HNMR}\left(400 \mathrm{MHz}, \mathrm{CDCl}_{3}\right), \delta 1.26\left(\mathrm{t}, J=7.2 \mathrm{~Hz}, 3 \mathrm{H}, \mathrm{CH}_{3}\right), 1.63(\mathrm{~d}, J$ $\left.=8.0 \mathrm{~Hz}, 3 \mathrm{H}, \mathrm{CHCH}_{3}\right), 3.83\left(\mathrm{~s}, 6 \mathrm{H}\right.$, pyrimidine- $\left.\underline{\mathrm{OCH}_{3}}\right), 4.23\left(\mathrm{q}, J=3.5 \mathrm{~Hz}, 2 \mathrm{H}, \mathrm{CH}_{2}\right), 4.73(\mathrm{q}, J$ $=6.8 \mathrm{~Hz}, 1 \mathrm{H}, \mathrm{CH}), 5.77(\mathrm{~s}, 1 \mathrm{H}$, pyrimidine-H), $6.88(\mathrm{~d}, J=8.8 \mathrm{~Hz}, 2 \mathrm{H}, \mathrm{ArH}), 7.11(\mathrm{~d}, J=8.8$ $\mathrm{Hz}, 2 \mathrm{H}, \mathrm{ArH})$. IR (KBr) v: 2987, 1746, 1502, $1195 \mathrm{~cm}^{-1}$. MS (m/z, \%): $348\left(\mathrm{M}^{+}, 100\right), 246(98)$, 375 (18). Anal. Calcd for $\mathrm{C}_{17} \mathrm{H}_{20} \mathrm{~N}_{2} \mathrm{O}_{6}$ : C, 58.61; H, 5.79; N, 8.04\%. Found: C, 58.42; H, 5.68; N, $8.15 \%$.

Methyl (R)-2-(4-(2-methylthio-6-trifluoromethylpyrimidin-4-yloxy)phenoxy)propanoate (11a). Yield 75\%, white solid, mp 101-102 ${ }^{\circ} \mathrm{C} .{ }^{1} \mathrm{H}$ NMR $\left(600 \mathrm{MHz}, \mathrm{CDCl}_{3}\right), \delta 1.65(\mathrm{~d}, J=6.6$ $\left.\mathrm{Hz}, 3 \mathrm{H}, \mathrm{CHCH}_{3}\right), 2.40$ (s, 3H, $\left.\underline{\mathrm{SCH}}_{3}\right), 3.78$ (s, 3H, $\left.\underline{\mathrm{OCH}}_{3}\right), 4.77$ (q, J = 6.8 Hz, 1H, CH), 6.79 (s, $1 \mathrm{H}$, pyrimidine-H), $6.93(\mathrm{~d}, J=9.0 \mathrm{~Hz}, 2 \mathrm{H}, \mathrm{ArH}), 7.06(\mathrm{~d}, J=9.0 \mathrm{~Hz}, 2 \mathrm{H}, \mathrm{ArH}) . \mathrm{IR}(\mathrm{KBr}) v$ : 1750, 1586, 1507, 1405, 1281, $1190 \mathrm{~cm}^{-1}$. MS (m/z, \%): $388\left(\mathrm{M}^{+}, 36\right), 284$ (43), 209 (78); Anal. Calcd for $\mathrm{C}_{16} \mathrm{H}_{15} \mathrm{~F}_{3} \mathrm{~N}_{2} \mathrm{O}_{4} \mathrm{~S}:$ C, 49.48; H, 3.89; N, 7.21\%. Found: C, 49.12; H, 4.01; N, $7.46 \%$.

Ethyl $(R)$-2-(4-(6-methyl-2-methylthiopyrimidin-4-yloxy)phenoxy)propanoate (11b). Yield 79\%, white solid, mp 83-84 ${ }^{\circ} \mathrm{C} .{ }^{1} \mathrm{H} \mathrm{NMR}\left(400 \mathrm{MHz} \mathrm{CDCl}_{3}\right.$ ), $\delta 1.27$ (t, $\left.J=6.3 \mathrm{~Hz}, 3 \mathrm{H}, \mathrm{CH}_{2} \underline{\mathrm{CH}}_{3}\right)$, $1.64\left(\mathrm{~d}, J=6.8 \mathrm{~Hz}, 3 \mathrm{H}, \mathrm{CHCH}_{3}\right), 2.38\left(\mathrm{~s}, 3 \mathrm{H}, \mathrm{ArCH}_{3}\right), 2.40\left(\mathrm{~s}, 3 \mathrm{H}, \mathrm{SCH}_{3}\right), 4.24$ (q, $J=6.3 \mathrm{~Hz}$, $\left.2 \mathrm{H}, \mathrm{CH}_{2}\right), 4.74(\mathrm{q}, J=6.8 \mathrm{~Hz}, 1 \mathrm{H}, \mathrm{CH}), 6.26(\mathrm{~s}, 1 \mathrm{H}$, pyrimidine-H), $6.90(\mathrm{~d}, J=8.8 \mathrm{~Hz}, 2 \mathrm{H}$, $\operatorname{ArH}), 7.05$ (d, $J=8.8 \mathrm{~Hz}, 2 \mathrm{H}, \mathrm{ArH})$. IR (KBr) v: 1747, 1196, 1276, 1250, $759 \mathrm{~cm}^{-1} . \mathrm{MS}(\mathrm{m} / \mathrm{z}$, \%): $348\left(\mathrm{M}^{+}, 41\right), 301$ (42), 300 (100). Anal. Calcd for $\mathrm{C}_{17} \mathrm{H}_{20} \mathrm{~N}_{2} \mathrm{O}_{4} \mathrm{~S}: \mathrm{C}, 58.60 ; \mathrm{H}, 5.79 ; \mathrm{N}$, 8.04\%. Found: C, 58.27; H, 5.83; N, 8.10\%.

Ethyl $(R)$-2-(4-(5,6-dimethyl-2-methylthiopyrimidin-4-yloxy)phenoxy)propanoate (11c). Yield 86\%, colourless needles, mp 73-75 ${ }^{\circ} \mathrm{C} .{ }^{1} \mathrm{H} \mathrm{NMR}\left(\mathrm{CDCl}_{3}, 400 \mathrm{MHz}\right), \delta 1.26$ (t, $J=.2 \mathrm{~Hz}$, $\left.3 \mathrm{H}, \mathrm{CH}_{2} \underline{\mathrm{CH}_{3}}\right), 1.63\left(\mathrm{~d}, J=6.8 \mathrm{~Hz}, 3 \mathrm{H}, \mathrm{CHCH}_{3}\right), 2.20$ (s, 3H, pyrimidine- $\left.\underline{\mathrm{CH}}_{3}\right), 2.46$ (s, 3H, pyrimidine $\left.-\underline{\mathrm{CH}}_{3}\right), 4.22\left(\mathrm{q}, J=7.2 \mathrm{~Hz}, 2 \mathrm{H}, \mathrm{CH}_{2}\right), 4.74(\mathrm{q}, J=6.8 \mathrm{~Hz}, 1 \mathrm{H}, \mathrm{CH}), 6.89(\mathrm{~d}, J=9.2$ $\mathrm{Hz}, 2 \mathrm{H}, \mathrm{ArH}), 7.03$ (d, $J=9.2 \mathrm{~Hz}, 2 \mathrm{H}, \mathrm{ArH})$. IR (KBr) v: 1753, 1196, 1296, $1206 \mathrm{~cm}^{-1}$. MS $(\mathrm{m} / \mathrm{z}$, \%): $362\left(\mathrm{M}^{+}, 100\right), 315$ (94), 289 (55), 260 (49). Anal. Calcd for $\mathrm{C}_{18} \mathrm{H}_{22} \mathrm{~N}_{2} \mathrm{O}_{4} \mathrm{~S}$ : C, 59.65; H, 6.12; N, 7.73\%. Found: C, 59.49; H, 6.07; N, 7.80\%.

Ethyl $(R)$-2-(4-(5-ethyl-6-methyl-2-methylthiopyrimidin-4-yloxy)phenoxy)propanoate (11d). Yield 74\%, colourless needles, mp 53-54 ${ }^{\circ} \mathrm{C} .{ }^{1} \mathrm{H} \mathrm{NMR}\left(400 \mathrm{MHz}, \mathrm{CDCl}_{3}\right), \delta 1.19(\mathrm{t}, J=7.5 \mathrm{~Hz}$, $3 \mathrm{H}$, pyrimidine- $\left.\mathrm{CH}_{2} \underline{\mathrm{CH}_{3}}\right), 1.26\left(\mathrm{t}, J=7.2 \mathrm{~Hz}, 3 \mathrm{H}, \mathrm{OCH}_{2} \underline{\mathrm{CH}}_{3}\right), 1.63\left(\mathrm{~d}, J=6.8 \mathrm{~Hz}, 3 \mathrm{H}, \mathrm{CHCH}_{3}\right)$, 2.22 (s, 3H, $\left.\mathrm{ArCH}_{3}\right), 2.45$ (s, $\left.3 \mathrm{H}, \underline{\mathrm{SCH}_{3}}\right), 2.68$ (q, J = $\left.7.5 \mathrm{~Hz}, 2 \mathrm{H}, \underline{\mathrm{CH}_{2}} \mathrm{CH}_{3}\right), 4.22$ (q, J = 7.2 Hz, 
$\left.2 \mathrm{H}, \mathrm{OCH}_{2} \mathrm{CH}_{3}\right), 4.74(\mathrm{q}, J=6.8 \mathrm{~Hz}, 1 \mathrm{H}, \mathrm{CH}), 6.89$ (d, J=8.8 Hz, 2H, ArH), 7.04 (d, $J=8.8 \mathrm{~Hz}$, 2H, ArH). IR (KBr) v: 1753, 1503, 1372, $1196 \mathrm{~cm}^{-1}$. MS (m/z, \%): $376\left(\mathrm{M}^{+}, 100\right), 329(62), 207$ (54), 101 (48). Anal. Calcd for $\mathrm{C}_{19} \mathrm{H}_{24} \mathrm{~N}_{2} \mathrm{O}_{4} \mathrm{~S}$ : C, 60.62; H, 6.43; N, 7.44\%. Found: C, 60.48; H, 6.36; N, 7.37\%.

Methyl $(R)$-2-(4-(6-methoxy-2-methylthiopyrimidin-4-yloxy)phenoxy)propanoate (11e). Yield 72\%, white solid, mp 82-84 ${ }^{\circ} \mathrm{C} .{ }^{1} \mathrm{H}$ NMR (400 MHz, $\left.\mathrm{CDCl}_{3}\right), \delta 1.64$ (d, J= 7.2 Hz, 3H, $\left.\mathrm{CHCH}_{3}\right), 2.44\left(\mathrm{~s}, 3 \mathrm{H}, \underline{\mathrm{SCH}}_{3}\right), 3.78\left(\mathrm{~s}, 3 \mathrm{H}, \underline{\mathrm{OCH}}_{3}\right), 3.93\left(\mathrm{~s}, 6 \mathrm{H}\right.$, pyrimidine-O $\left.\underline{\mathrm{CH}}_{3}\right), 4.75$ (q, $J=$ $7.2 \mathrm{~Hz}, 1 \mathrm{H}, \mathrm{CH}), 5.66$ (s, 1H, pyrimidine-H), $6.88(\mathrm{~d}, J=8.8 \mathrm{~Hz}, 2 \mathrm{H}, \mathrm{ArH}), 7.04$ (d, J = 8.8 Hz, 2H, ArH). IR (KBr) v: 3453, 1753, 1576, $1204 \mathrm{~cm}^{-1}$. MS (m/z, \%): $350\left(\mathrm{M}^{+}, 41\right), 303$ (100), 215 (10); Anal. Calcd for $\mathrm{C}_{16} \mathrm{H}_{15} \mathrm{~F}_{3} \mathrm{~N}_{2} \mathrm{O}_{4} \mathrm{~S}$ : C, 54.85; H, 5.18; N, 7.99\%. Found: C, 54.92; H, 5.06; N, $8.09 \%$.

Methyl (R)-2-(4-(6-methylamino-2-methylthiopyrimidin-4-yloxy)phenoxy)propanoate (11f). Yield 70\%, white solid, mp 85-86 ${ }^{\circ} \mathrm{C} .{ }^{1} \mathrm{H}$ NMR (600 MHz, $\left.\mathrm{CDCl}_{3}\right), \delta 1.63(\mathrm{~d}, J=6.8 \mathrm{~Hz}, 3 \mathrm{H}$, $\left.\mathrm{CHCH}_{3}\right), 2.38\left(\mathrm{~s}, 3 \mathrm{H}, \underline{\mathrm{SCH}}_{3}\right), 3.78\left(\mathrm{~s}, 3 \mathrm{H}, \mathrm{OCH}_{3}\right), 3.95\left(\mathrm{~d}, J=4.8 \mathrm{~Hz}, 3 \mathrm{H}, \mathrm{NHCH}_{3}\right), 4.74(\mathrm{q}, J=$ $6.8 \mathrm{~Hz}, 1 \mathrm{H}, \mathrm{CH}), 5.05(\mathrm{~s}, 1 \mathrm{H}, \mathrm{NH}), 5.29(\mathrm{~s}, 1 \mathrm{H}, \mathrm{ArH}), 6.89(\mathrm{~d}, J=9.0 \mathrm{~Hz}, 2 \mathrm{H}, \mathrm{ArH}), 7.05(\mathrm{~d}, J=$ $9.0 \mathrm{~Hz}, 2 \mathrm{H}, \mathrm{ArH})$. IR (KBr) v: 3273, 1751, 1584, $1209 \mathrm{~cm}^{-1} . \mathrm{MS}(\mathrm{m} / z, \%): 349\left(\mathrm{M}^{+}, 55\right), 262$ (65), 195 (100). Anal. Calcd for $\mathrm{C}_{16} \mathrm{H}_{19} \mathrm{~N}_{3} \mathrm{O}_{4} \mathrm{~S}$ : C, 55.00; H, 5.48; N, 12.03\%. Found: C, 55.32; H, 5.39; N, $12.25 \%$.

Ethyl (R)-2-(4-(6-chloro-2-methylthiopyrimidin-4-yloxy)phenoxy)propanoate (11g). Yield $72 \%$, white solid, mp 60-61 ${ }^{\circ} \mathrm{C} .{ }^{1} \mathrm{H}$ NMR $\left(400 \mathrm{MHz}, \mathrm{CDCl}_{3}\right), \delta 1.27(\mathrm{t}, J=7.2 \mathrm{~Hz}, 3 \mathrm{H}$, $\left.\mathrm{CH}_{2} \underline{\mathrm{CH}}_{3}\right), 1.64$ (d, J=6.4 Hz, 3H, $\left.\mathrm{CHCH}_{3}\right), 2.35$ (s, 3H, pyrimidine- $\left.\underline{\mathrm{CH}}_{3}\right), 2.39$ (s, 3H, $\left.\underline{\mathrm{SCH}}_{3}\right)$, 4.24 (q, $J=3.2 \mathrm{~Hz}, 2 \mathrm{H}, \mathrm{CH}_{2}$ ), 4.74 (q, $\left.J=6.8 \mathrm{~Hz}, 1 \mathrm{H}, \mathrm{CH}\right), 6.44$ (s, 1H, pyrimidine-H), 6.91 (d, $J=9.2 \mathrm{~Hz}, 2 \mathrm{H}, \mathrm{ArH}), 7.04(\mathrm{~d}, J=9.2 \mathrm{~Hz}, 2 \mathrm{H}, \mathrm{ArH})$. IR (KBr) v: 2994, 1741, 1503, $1192 \mathrm{~cm}^{-1}$. MS (m/z, \%): $368\left(\mathrm{M}^{+}, 35\right), 266$ (100), 109 (47). Anal. Calcd for $\mathrm{C}_{16} \mathrm{H}_{17} \mathrm{ClN}_{2} \mathrm{O}_{4} \mathrm{~S}: \mathrm{C}, 52.10 ; \mathrm{H}$, 4.65; N, 7.60\%. Found: C, 52.34; H, 4.32; N, 7.43\%.

Methyl (R)-2-(4-(6-chloro-2-methylthio-5-nitropyrimidin-4-yloxy)phenoxy)propanoate (11h). Yield 78\%, colourless needles, mp 107-108 ${ }^{\circ} \mathrm{C} .{ }^{1} \mathrm{H}$ NMR $\left(600 \mathrm{MHz}, \mathrm{CDCl}_{3}\right), \delta 1.65(\mathrm{~d}, J$ $\left.=6.6 \mathrm{~Hz}, 3 \mathrm{H}, \mathrm{CHCH}_{3}\right), 2.35\left(\mathrm{~s}, 3 \mathrm{H}, \underline{\mathrm{SCH}}_{3}\right), 3.78\left(\mathrm{~s}, 3 \mathrm{H}, \underline{\mathrm{OCH}}_{3}\right), 4.77(\mathrm{q}, J=6.8 \mathrm{~Hz}, 1 \mathrm{H}, \mathrm{CH})$, $6.91(2 \mathrm{~d}, J=9.0 \mathrm{~Hz}, \mathrm{H}, \mathrm{ArH}), 7.08(\mathrm{~d}, J=8.4 \mathrm{~Hz}, 2 \mathrm{H}, \mathrm{ArH}) . \mathrm{IR}(\mathrm{KBr}) v: 3437,1741,1548$, $1187 \mathrm{~cm}^{-1}$. MS (m/z,\%): $399\left(\mathrm{M}^{+}, 42\right), 364$ (36), 32 (78). Anal. Calcd for $\mathrm{C}_{15} \mathrm{H}_{14} \mathrm{ClN}_{3} \mathrm{O}_{6} \mathrm{~S}: \mathrm{C}$, 45.06; H, 3.53; N, 10.51\%. Found: C, 45.31; H, 3.56; N, $10.81 \%$.

Ethyl (R)-2-(4-(2-methylthio-6-phenylpyrimidin-4-yloxy)phenoxy)propanoate (11i). Yield $79 \%$, white solid, mp 91-93 ${ }^{\circ} \mathrm{C} .{ }^{1} \mathrm{H} \mathrm{NMR}\left(400 \mathrm{MHz}, \mathrm{CDCl}_{3}\right.$ ), $\delta 1.27$ (t, J=7.2 Hz, 3H, $\left.\mathrm{OCH}_{2} \underline{\mathrm{CH}_{3}}\right), 1.65$ (d, J=6.8 Hz, 3H, $\left.\mathrm{CHCH}_{3}\right), 2.48$ (s, 3H, $\left.\underline{\mathrm{SCH}}_{3}\right), 4.25$ (q, $J=7.2 \mathrm{~Hz}, 2 \mathrm{H}$, $\left.\mathrm{OCH}_{2} \mathrm{CH}_{3}\right), 4.75(\mathrm{q}, J=6.8 \mathrm{~Hz}, 1 \mathrm{H}, \mathrm{CH}), 6.82(\mathrm{~s}, 1 \mathrm{H}$, pyrimidine- $\mathrm{H}), 6.92(\mathrm{~d}, J=8.8 \mathrm{~Hz}, 2 \mathrm{H}$, ArH), 7.10 (d, $J=8.8 \mathrm{~Hz}, 2 \mathrm{H}, \mathrm{ArH}), 8.02-7.48$ (m, 5H, ArH). IR (KBr) v:1761, 1184, 1263, 1205 $\mathrm{cm}^{-1}$. MS (m/z, \%): $410\left(\mathrm{M}^{+}, 67\right), 363$ (100), 207 (34.05), 128 (88.77). Anal. Calcd for $\mathrm{C}_{22} \mathrm{H}_{22} \mathrm{~N}_{2} \mathrm{O}_{4} \mathrm{~S}$ : C, 64.37; H, 5.40; N, 6.82_\%. Found: C, 64.49; H, 5.36; N, 6.90\%.

Methyl (R)-2-(4-(6-chloro-2-methoxypyrimidin-4-yloxy)phenoxy)propanoate (11j). Yield $78 \%$, colourless needles, mp 81-82 ${ }^{\circ} \mathrm{C} .{ }^{1} \mathrm{H}$ NMR (600 MHz, $\left.\mathrm{CDCl}_{3}\right), \delta 1.63$ (d, $J=6.8 \mathrm{~Hz}, 3 \mathrm{H}$, 
$\left.\mathrm{CHCH}_{3}\right), 3.78\left(\mathrm{~s}, 3 \mathrm{H}, \underline{\mathrm{OCH}}_{3}\right), 3.91$ (s, 3H, pyrimidine- $\left.\underline{\mathrm{OCH}}_{3}\right), 4.75$ (q, J=6.8 Hz, 1H, CH), 6.45 (s, 1H, pyrimidine-H), $6.90(\mathrm{~d}, J=7.8 \mathrm{~Hz}, 2 \mathrm{H}, \mathrm{ArH}), 7.05(\mathrm{~d}, J=7.8 \mathrm{~Hz}, 2 \mathrm{H}, \mathrm{ArH}) . \mathrm{IR}(\mathrm{KBr}) v$ : 3445, 1735, 1572, $1201 \mathrm{~cm}^{-1}$. MS (m/z,\%): $338\left(\mathrm{M}^{+}, 72\right), 216$ (82), 159 (60). Anal. Calcd for $\mathrm{C}_{15} \mathrm{H}_{15} \mathrm{ClN}_{2} \mathrm{O}_{5}: \mathrm{C}, 53.19 ; \mathrm{H}, 4.46 ; \mathrm{N}, 8.27 \%$. Found: C, 53.40; H, 4.38; N, 8.39\%.

Methyl (R)-2-(4-(2,6-dimethoxypyrimidin-4-yloxy)phenoxy)propanoate (11k). Yield: 70\%, white solid, mp 40-41 ${ }^{\circ} \mathrm{C} .{ }^{1} \mathrm{H}$ NMR $\left(600 \mathrm{MHz}, \mathrm{CDCl}_{3}\right), \delta 1.63\left(\mathrm{~d}, J=6.8 \mathrm{~Hz}, 3 \mathrm{H}, \mathrm{CHCH}_{3}\right), 3.78$ $\left(\mathrm{s}, 3 \mathrm{H}, \mathrm{OCH}_{3}\right), 3.90\left(\mathrm{~s}, 3 \mathrm{H}\right.$, pyrimidine- $\left.\underline{\mathrm{OCH}}_{3}\right), 3.95\left(\mathrm{~s}, 3 \mathrm{H}\right.$, pyrimidine- $\left.\underline{\mathrm{OCH}}_{3}\right), 4.74(\mathrm{q}, J=6.8$ $\mathrm{Hz}, 1 \mathrm{H}, \mathrm{CH}), 5.64$ (s, 1H, pyrimidine-H), 6.89 (d, $J=9.0 \mathrm{~Hz}, 2 \mathrm{H}, \mathrm{ArH}), 7.05$ (d, J=9.0 Hz, 2H, ArH); IR (KBr) v: 3441, 1736, 1591, $1207 \mathrm{~cm}^{-1}$. MS (m/z, \%): 334 (M+, 64), 247 (100), 155 (58). Anal. Calcd for $\mathrm{C}_{16} \mathrm{H}_{18} \mathrm{~N}_{2} \mathrm{O}_{6}: \mathrm{C}, 57.48 ; \mathrm{H}, 5.43 ; \mathrm{N}, 8.38 \%$. Found: C, 57.65; H, 5.46; N, 8.22\%.

Methyl (R)-2-(4-(2,6-diethoxypyrimidin-4-yloxy)phenoxy)propanoate (111). Yield 70\%, white solid, mp 54-56 ${ }^{\circ} \mathrm{C} .{ }^{1} \mathrm{H} \mathrm{NMR}\left(600 \mathrm{MHz} \mathrm{CDCl}_{3}\right), \delta 1.34\left(\mathrm{t}, J=6.9 \mathrm{~Hz}, 3 \mathrm{H}, \mathrm{CH}_{3}\right), 1.37$ (t, $J$ $\left.=6.9 \mathrm{~Hz}, 3 \mathrm{H}, \mathrm{CH}_{3}\right), 1.63\left(\mathrm{~d}, J=6.8 \mathrm{~Hz}, 3 \mathrm{H}, \mathrm{CHCH}_{3}\right), 3.75\left(\mathrm{~s}, 3 \mathrm{H}, \mathrm{OCH}_{3}\right), 4.32$ (q, $J=6.9 \mathrm{~Hz}$, $\left.2 \mathrm{H}, \mathrm{CH}_{2}\right), 4.37\left(\mathrm{q}, J=6.9 \mathrm{~Hz}, 2 \mathrm{H}, \mathrm{CH}_{2}\right), 4.74(\mathrm{q}, J=6.8 \mathrm{~Hz}, 1 \mathrm{H}, \mathrm{CH}), 5.59$ (s, 1H, pyrimidineH), $6.90(\mathrm{~d}, J=9.0 \mathrm{~Hz}, 2 \mathrm{H}, \mathrm{ArH}), 7.04$ (d, $J=9.0 \mathrm{~Hz}, 2 \mathrm{H}, \mathrm{ArH})$. IR (KBr) v: 3400, 1743, 1609, $1202 \mathrm{~cm}^{-1}$. MS (m/z, \%): $362\left(\mathrm{M}^{+}, 70\right), 275$ (95), 195 (86). Anal. Calcd for $\mathrm{C}_{18} \mathrm{H}_{22} \mathrm{~N}_{2} \mathrm{O}_{6}$ : C, 59.66; H, 6.12; N, 7.73\%. Found: C, 59.82; H, 6.33; N, 7.92\%.

Methyl $(R)$-2-(4-(6-chloro-2-methylaminopyrimidin-4-yloxy)phenoxy)propanoate (11m). Yield 72\%, white solid, mp 90-91 ${ }^{\circ} \mathrm{C} .{ }^{1} \mathrm{H}$ NMR (400 $\left.\mathrm{MHz} \mathrm{CDCl}_{3}\right), \delta 1.63(\mathrm{~d}, J=6.8 \mathrm{~Hz}, 3 \mathrm{H}$, $\left.\mathrm{CHCH}_{3}\right), 2.89\left(\mathrm{~d}, J=4.8 \mathrm{~Hz}, 3 \mathrm{H}, \mathrm{NHCH}_{3}\right), 3.78\left(\mathrm{~s}, 3 \mathrm{H}, \mathrm{OCH}_{3}\right), 4.74(\mathrm{q}, J=6.8 \mathrm{~Hz}, 1 \mathrm{H}, \mathrm{CH})$, $5.44(\mathrm{~s}, 1 \mathrm{H}, \mathrm{NH}), 6.07(\mathrm{~s}, 1 \mathrm{H}$, pyrimidine-H), $6.86(\mathrm{~d}, J=9.2 \mathrm{~Hz}, 2 \mathrm{H}, \mathrm{ArH}), 7.08$ (d, J = $8.8 \mathrm{~Hz}$ 2H, ArH). IR (KBr) v: 3426, 1752, 1618, $1194 \mathrm{~cm}^{-1} . \mathrm{MS}(\mathrm{m} / z, \%): 337\left(\mathrm{M}^{+}, 42\right), 302(65), 180$ (79). Anal. Calcd for $\mathrm{C}_{15} \mathrm{H}_{16} \mathrm{ClN}_{3} \mathrm{O}_{4}$ : C, 53.34; H, 4.77; N, 12.44\%. Found: C, 53.60; H, 4.58; N, $12.44 \%$.

\section{Acknowledgements}

We gratefully acknowledge the financial supports by the National Natural Science Foundation of China (Project Nos.: 20972056, 20672044).

\section{References}

1. Nikolau, B. J.; Wurtel, E. S. Arch. Biochem. Biophys. 2003, 414, 211.

2. Konishi, T.; Shinohara, K.; Yamada, K.; Sasaki, Y. Plant and Cell Physiology 1996, 37, 117.

3. Delye, C.; Zhang, X. Q.; Michel, S.; Matejicek, A.; Powles, S. B. Plant Physiol. 2005, 137, 794.

4. Delye, C. Weed Science 2005, 53, 728.

5. Shukla, A.; Nycholat, C.; Mani, V. S.; Richard, J. A.; Malaolm, D. D. J. Agric. Food Chem. 
2004, 52, 5144.

6. Zhang, H. L.; Tweel, B. J.; Tong, L. Pnas 2004, 101, 5910.

7. Zhu, X. L.; Zhang, L.; Chen, Q.; Wan, J.; Yang, G. F. J. Chem. Inf. Model. 2006, 46, 1819.

8. Lima, L. M.; Barreiro, E. J. Curr. Med. Chem. 2005, 12, 23.

9. Johnson, T. C.; Martin, T. P.; Mann, R. K.; Pobanz, M. A. Bioorg. Med. Chem. 2009, 17, 4230.

10. Zhao, Y.; Wang, G.; Dong, W. L.; Li, Z. M. Arkivoc 2010, (ii), 16.

11. Lummen, P. Biochim. Biophys. Acta 1998, 1364, 287.

12. (a) Cartwright, D.; Salmon, R. U.S. Patent 4246 419. (b) Serban, A.; Warner, R. B.; Watson, K. G. U.S. Patent 4248 618. (c) Rogers, R. B. U.S. Patent 4750 931. (d) Bird, G. J.; Cross, L. E. Watson, K. G. Bioorg. Med. Chem. Lett. 1997, 7, 1489.

13. Delye, C.; Zhang, X. Q.; Chalopin, C.; Michel, S.; Powles, S. B.; Plant Physiol 2003, 132, 1716.

14. Hoppe, H. H.; Zacher, H.; Pestic. Biochem. Physiol. 1985, 24, 298.

15. Zhang, H. L.; Yang, Z. R.; Shen, Y.; Tong, L. Science 2003, 299, 2064.

16. Schwede, T.; Kopp, J.; Guex, N.; Peitsch, M. C. Nucleic Acids Res. 2003, 31, 3381.

17. Petricci, E.; Mugnaini, C.; Radi, M.; Botta, M. Arkivoc 2006, (vii), 452.

18. Zhu, Y. Q.; Wu, C.; Li, H. B.; Zou, X. M. J. Agric. Food Chem. 2007, 55, 1364.

19. Shiki, K. M.; Akiyama, S.; Fukuda, K. U.S. Patent 4665212.

20. Rittner, S. DE 3316061 A1.

21. Foster, H. M.; Snyder, H. R. Org. Syn. 1963, 4, 638.

22. Sloop, J. C.; Bumgardner, C. L. J. Fluorine Chem. 2002, 118, 135.

23. Ostrowski, S.; Swat, J.; Mąkosza, M. Arkivoc 2000, (vi), 905.

24. Wheeler, H. L. J. Am. Chem. Soc. 1910, 42, 431.

25. Ple, N.; Turck, A.; Couture, K.; Queguiner, G. Tetrahedron 1994, 50, 10299.

26. Gaetano, D. A. J. Med. Chem. 1984, 27, 1621.

27. Brown, D. J.; Jacobsen, N. W. J. Chem. Soc. Perkin Trans. 1 1965, 3770.

28. Harnden, M. R.; Hurst, D. T. Aus. J. Chem. 1990, 43, 55.

29. Nezu, Y.; Miyazaki, M.; Sugiyama, K. Pestic. Sci. 1996, 47, 103. 